Published in "Bulletin of the Peabody Museum of Natural History

57(1): 21-56, 2016"

which should be cited to refer to this work.

\title{
A Review of the Fossil Record of Turtles of the Clade Pan-Chelydridae
}

\author{
Walter G. Joyce \\ Corresponding author: Department of Geosciences, University of Fribourg, 1700 Fribourg, Switzerland \\ -email: walter.joyce@unifr.ch
}

\begin{abstract}
Turtles of the total clade Pan-Chelydridae have a relatively sparse fossil record that reaches back to the Late Cretaceous (Santonian). The clade was only present in North America during the Cretaceous but spread along unclear routes to Asia and Europe during the Paleocene, only to go extinct on those continents by the end of the Pliocene. Final dispersal to South America took place at some time during the late Neogene. The ecology of stem chelydrids seems to have been similar to that of the extant Chelydra serpentina, although more primitive representatives were more molluscivorous as inferred from their broader triturating surfaces. Current phylogenies only recognize five internested clades: Pan-Chelydridae, Chelydridae, Chelydropsis, Chelydra and Macrochelys. A taxonomic review of the group concludes that of 31 named fossil taxa, 8 are nomina valida, 10 are nomina invalida, 9 are nomina dubia, 1 is a nomen nudum and 1 is a regular, unavailable name.
\end{abstract}

KEYWORDS

Phylogeny, Biogeography, Paleoecology, Pan-Chelydridae, Chelydridae, Chelydropsis

\section{Introduction}

The term Pan-Chelydridae refers to the total clade of Chelydridae, which is the crown clade arising from the most recent common ancestor of the common snapping turtle Chelydra serpentina (Linnaeus, 1758) and the alligator snapping turtle Macrochelys temminckii (Troost in Harlan, 1835). Historically, chelydrids (i.e., snapping turtles) were recognized to have close relationships with kinosternoids (i.e., mud and musk turtles), mostly based on characters derived from the shell, such as the presence of costiform processes and a cruciform plastron (e.g., Gray 1869; Boulenger 1889; Baur 1893; Siebenrock 1909; Williams 1950; Romer 1956; Kuhn 1964; Sukhanov 1964; Mkynarski 1976; Carroll 1988), but early classifications often failed to include important taxa in this grouping, particularly the Central American river turtle Dermatemys mawii Gray, 1847, or wrongfully included others, such as the aberrant Asian big-headed turtle Platysternon megacephalum Gray, 1831.

With the advent of cladistic methods, Gaffney (1975a, 1975b) suggested that cranial characters link chelydrids with testudinoid turtles and that Platysternon megacephalum should be regarded as a true snapping turtle. Subsequent cladistic analyses supported the distinct nature of pan-chelydrids and placed this clade as sister either to all other extant cryptodires (e.g., Gaffney et al. 1991; Hirayama et al. 2000; Tong et al. 2009) or to testudinoids and trionychoids (e.g., Brinkman and Wu 1999; Joyce 2007). A series of increasingly well-sampled analyses that utilize molecular data (e.g., Shaffer et al. 1997; Krenz et al. 2005; Parham et al. 2006; Barley et al. 2010; Crawford et al. 2015), however, have more recently revived the sister group relationship between chelydrids and kinosternoids to the exclusion of $P$. megacephalum. This resulting "superfamilial" clade is named Chelydroidea following Baur (1893), who was the first to recognize this exact arrangement (Knauss et al. 2011). Although current morphological studies still fail to retrieve a monophyletic Chelydroidea (e.g., Joyce 2007; Anquetin 2012; Sterli et al. 2013; Rabi et al. 2014), some compelling character evidence is nevertheless available that supports the monophyly of this clade (Knauss et al. 2011). 
Throughout the 19th century, fossil panchelydrids were only known from Oligocene to Pliocene deposits in Germany (Bell 1836; Meyer 1845, 1852; Winkler 1869; Fraas 1870) and Austria (Peters 1855, 1868, 1869; Gross 2002), far outside the current distribution of the clade in North and South America; however, their attribution to Pan-Chelydridae was always unambiguous, as these finds include complete skeletons that clearly reveal their phylogenetic affinities. The European fossil record was only later supplemented by mostly fragmentary finds from the Czech Republic (Laube 1900, 1910), France (Broin 1977), Kazakhstan (Chkhikvadze 1971, 1973), Moldova (Khosatzky and Redkozubov 1989), Poland (Mlynarski 1981a, 1981b), Romania (Młynarski 1966, 1969), Slovakia (Młynarski 1963; Danilov et al. 2012), Spain (Murelaga et al. 1999; Murelaga et al. 2002), Ukraine (Pidoplichko and Tarashchuk 1960; Tarashchuk 1971), and Turkey (Paicheler et al. 1978). Additional fossil material has been reported from Georgia and Russia (see Syromyatnikova et al. 2013 for a summary); however, none has been figured, and it is therefore not possible to reproduce these reports.

The fossil record of North American panchelydrids remained elusive throughout the 19th century (Hay 1908b). Some well-preserved skulls were finally described in the mid-20th century from Neogene sediments (e.g., Matthew 1924; Zangerl 1945; Dobie 1968; Whetstone 1978a), and their attribution to crown Chelydridae, in particular the Macrochelys lineage, was uncontroversial once again, as these beautifully preserved fossils clearly revealed many unambiguous apomorphies. The Neogene record has since only been supplemented by fragmentary postcranial remains with less certain phylogenetic affiliations. Relatively rich remains of more basal pan-chelydrids have otherwise been retrieved more recently from Late Cretaceous (Campanian) to Paleocene sediments throughout western North America, in particular the Santonian and Campanian of Alberta, Canada (Brinkman 2003; Brinkman and Eberth 2006); the Campanian of Mexico (Rodriguez-de la Rosa and Cevallos-Ferriz 1998) and Utah, USA (Hutchison et al. 2013); and the Maastrichtian to Paleocene of Montana, North Dakota and Wyoming, USA (Erickson 1973, 1982, 1984, 2010; Hutchison and Archibald 1986; Holroyd and Hutchison 2002; Hutchison 2013; Holroyd et al. 2014).
Given that pan-chelydrids and pan-kinosternoids originate from a common ancestor, it is sometimes difficult to rigorously distinguish early representatives of both groups from one another. For instance, Chkhikvadze (1973) suggested that Paleocene Hoplochelys spp. from North America should be considered to be pan-chelydrids based on the presence of a cruciform plastron and the absence of a midline contact of the abdominal scutes, but Hutchison and Bramble (1981) later highlighted the affinities of Hoplochelys spp. with pan-kinosternoids, a conclusion supported by more recent analyses (e.g., Knauss et al. 2011). Similarly, the Late Cretaceous (Maastrichtian) Emarginachelys cretacea Whetstone, 1978 was originally described as a pan-chelydrid (Whetstone 1978b) but was later reinterpreted to be a pan-kinosternoid, although an explicit rationale was not provided for this assessment (e.g., Meylan and Gaffney 1989; Holroyd and Hutchison 2002; Holroyd et al. 2014). Although the available character evidence is conflicting, I here agree that $E$. cretacea is a pan-kinosternoid and therefore discuss it elsewhere (see Joyce and Bourque 2016). Finally, although Tullochelys montana Hutchison, 2013 from the early Paleocene of Montana was recently described as a new species of pan-chelydrid, I tentatively regard this as a pan-kinosternoid and therefore discuss it elsewhere as well (see Joyce and Bourque 2016).

For institutional abbreviations, see Appendix 1. Named pan-chelydrid genera are listed in Appendix 2.

\section{Skeletal Morphology}

\section{Cranium}

Chelydra serpentina is an extremely common turtle throughout North America, and skeletal material has been available to researchers for much of the past two centuries; however, early descriptions are lacking, beyond figures presented in Boulenger (1889). This situation was thoroughly mitigated by Gaffney (1972) who provided a systematic revision of the nomenclatural pertaining to the cranial anatomy of turtles and utilized Chelydra serpentina to illustrate most of the structures. The cranial anatomy of Chelydra serpentina and Macrochelys temminckii is otherwise discussed in Gaffney $(1975 b, 1979)$ as part of a general revision of the cranial anatomy of all turtles. 
Additional insights into the anatomy of Macrochelys spp. were finally provided by Thomas et al. (2014). Among fossil pan-chelydrids, the cranial anatomy is known for Protochelydra zangerli (Erickson 1973, 2010), Chelydropsis murchisoni (Pidoplichko and Tarashchuk 1960; Tarashchuk 1971; Broin 1977; Mlynarski 1981b; Gaffney and Schleich 1994), M. auffenbergi (Dobie 1968), M. schmidti (Zangerl 1945; Whetstone 1978a) and M. stricta (Matthew 1924). Some additional skulls are known from the fossil record, but these are either preserved in slabs (e.g., Bell 1836; Meyer 1845) or represent poorly ossified juveniles (e.g., Meyer 1852, 1854, 1865; Paicheler et al. 1978) and therefore do not provide much anatomical information.

The skulls of pan-chelydrids are relatively large relative to the body and triangular when viewed dorsally. Extant Macrochelys are extremely macrocephalic and are therefore not able to fully withdraw their head inside the shell. The eyes of most taxa are oriented dorsolaterally (Figure 1B, C), but those of Macrochelys spp. are oriented laterally (Figure 1A). The upper temporal emargination ranges from intermediate to deep, but the lower temporal emargination generally remains shallow. Ridges and crenulations cover the skull surface in Chelydra spp.

The prefrontals are large and contact one another along the midline (Figure 1). The descending process is well developed and contacts the palatine and vomer distally and helps define a keyhole-shaped fissura ethmoidalis. The frontals are reduced in size and clearly do not contribute to the orbits in any taxon. The parietals are relatively large elements that form a broad descending process that contacts the palatines, pterygoids and epipterygoids ventrally and helps enclose the trigeminal foramen. The postorbitals are large elements that contribute to the rim of the orbit anteriorly, the upper temporal emargination posteriorly, and broadly contact the squamosals.

The premaxillae are small, paired elements that help define a pair of prepalatine foramina. The maxillae are large elements that often approach the quadratojugal closely posteriorly (Figure 1A) but never form an actual contact. The jugals are relatively elongate elements that symplesiomorphically contribute to the margin of the orbit (Figure 1A, B), with the notable exception of Chelydropsis spp. (Figure 1C). The quadrates are relatively large and frame the anterior margin of the cavum tympani. The squamosals universally lack an anterolateral contact with the parietals.

A premaxillary "hook" is particularly well developed among Macrochelys spp., relatively minor in Chelydra serpentina and absent in stem chelydrids. The premaxillae and maxillae, and sometimes the palatines, form intermediately broad and flat triturating surfaces, but some individuals of Chelydropsis murchisoni and Protochelydra zangerli exhibit extremely broad crushing surfaces. Pan-chelydrids consistently lack any signs of a secondary palate. The labial ridges are typically well developed, but minute lingual ridges are only present in some representatives of Macrochelys. The vomer is well developed and clearly separates the palatines. The pterygoids are large elements that broadly floor the otic region and posteriorly contact the basioccipital and exoccipitals. The external processes of the pterygoids are well developed and possess enlarged vertical flanges. The ventral exposure of the basisphenoid is relatively reduced, but never absent.

The cavum tympani of pan-chelydrids is formed by the quadrate, is relatively small and is often high oval in shape (Figure 1). The anterior margin of the vertically oriented antrum postoticum is formed by the quadrate. The incisura columella auris is enclosed but does not include the Eustachian duct. The trochlear process is mostly formed by the quadrate with a small contribution from the prootic. The process is clearly defined in all taxa but deeply protrudes into the temporal fossa in Macrochelys spp. The stapedial foramen is relatively large and placed relatively far to the anterior on top of the otic cavity. The supraoccipital forms an elongate and notable high crest that protrudes far beyond the level of the basioccipital.

The relatively small internal carotid artery enters the skull at the back of the skull in a foramen formed by the pterygoid. The exoccipitals form an enlarged bony flange that broadly covers the perilymphatic sack and that helps define the posterior jugular foramen. The remaining postotic fenestra, however, remains wide open. The exoccipitals and basioccipital otherwise help define two pairs of hypoglossal foramina.

The mandibles lack splenials and notable retroarticular processes. The triturating surface is generally simple but exhibits a well-formed midline "hook" in Macrochelys spp. 
A

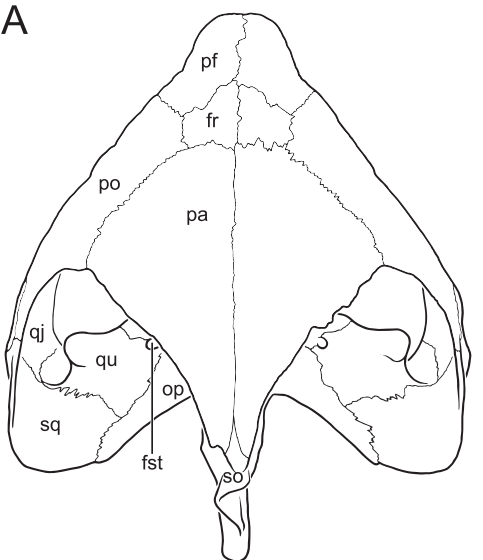

Macrochelys temminckii

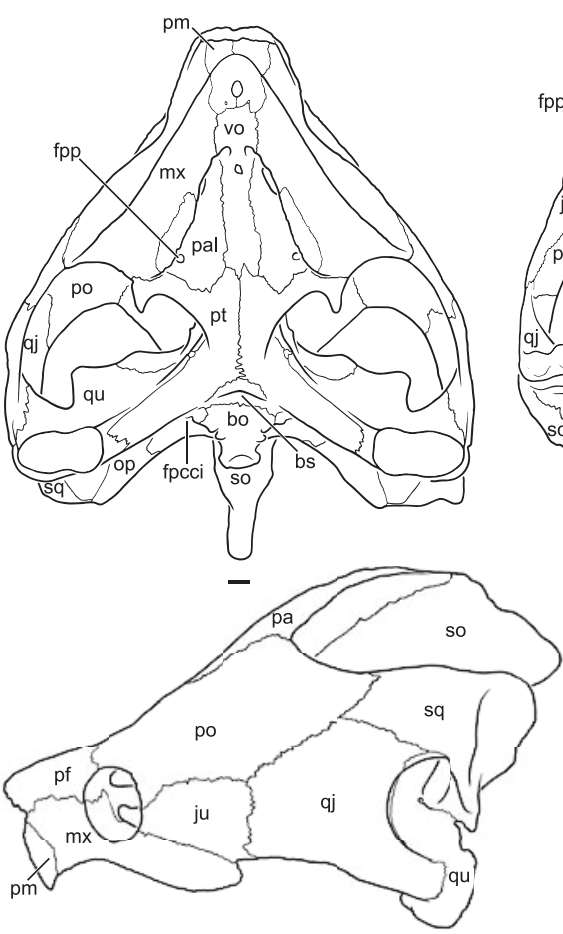

B

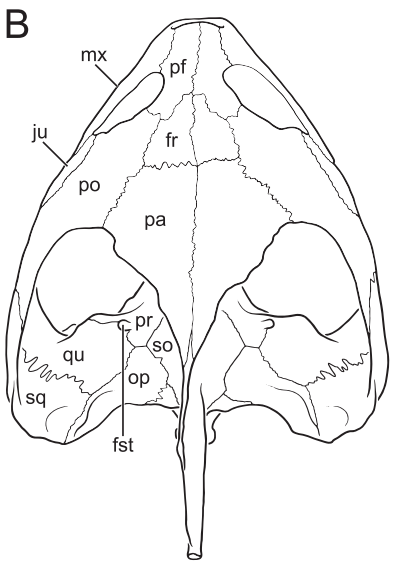

Chelydra serpentina

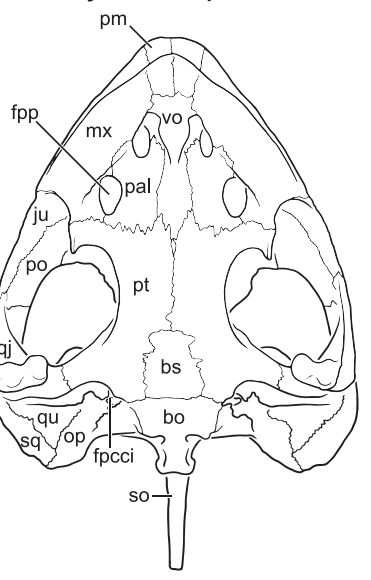

C

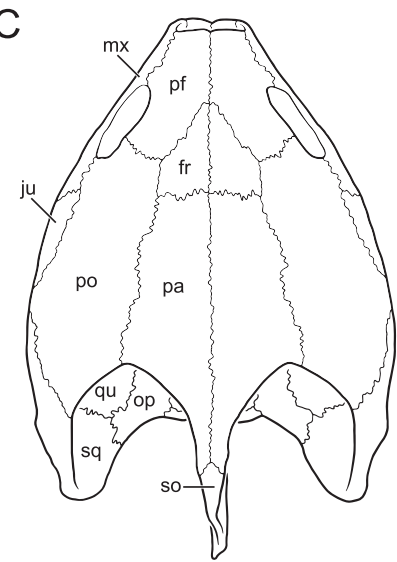

Chelydropsis murchisoni

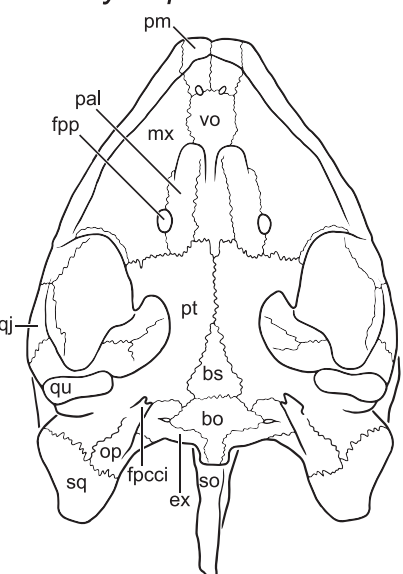

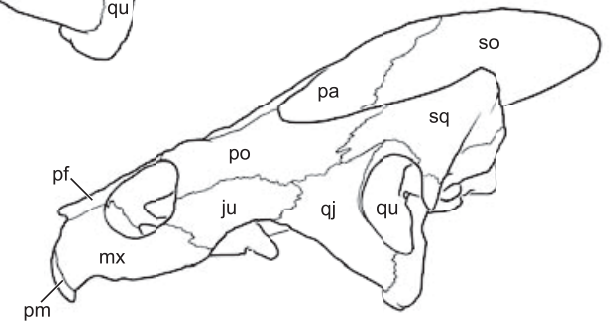

FIGURE 1. Cranial morphology of Pan-Chelydridae as exemplified by three species. A, Macrochelys temminckii (USNM 266207). B, Chelydra serpentina (USNM 310703). C, Chelydropsis murchisoni (redrawn from Gaffney and Schleich 1994). Abbreviations: bo, basioccipital; bs, basisphenoid; ex, exoccipital; fpcci, foramen posterius canalis carotici interni; fpp, foramen palatinum posterius; fr, frontal; fst, foramen stapedio-temporale; ju, jugal; $\mathrm{mx}$, maxilla; op, opisthotic; pa, parietal; pal, palatine; pf, prefrontal; pm, premaxilla; po, postorbital; pr, prootic; pt, pterygoid; qj, quadratojugal; qu, quadrate; so, supraoccipital; sq, squamosal; vo, vomer. Scale bar approximates $1 \mathrm{~cm}$. 
Shell

Original illustrations of extant shells are available for Chelydra serpentina (Meyer 1852; Boulenger 1889) and Macrochelys temminckii (Boulenger 1889), in addition to the ones provided herein. For fossil taxa, useful descriptions or illustrations of fossil shell material are provided for Chelydropsis decheni (Meyer 1852; Broin 1977), Chelydropsis kusnetzovi (Chkhikvadze 1987), Chelydropsis murchisoni (Bell 1836; Meyer 1845, 1852; Peters 1869; Winkler 1869; Myynarski 1980b; Gaffney and Schleich 1994), Denverus middletoni (Hutchison and Holroyd 2003) and Protochelydra zangerli (Erickson 1982). However, among fossil material, no taxon is sufficiently figured to allow presenting a rigorous reconstruction herein.

The carapaces of pan-chelydrids are generally broad and rounded, but well-developed nuchal and pygal notches are apparent in Macrochelys temminckii. The posterior margin is typically serrated. Traces of three carapacial keels are present in all species, with the exception of $M$. temminckii, which exhibits three rows of highly distinct tubercles that correspond with the scutes. Costal fontanelles are apparent in crown chelydrids, but absent in all stem representatives. The carapace normally consists of a nuchal, 8 neurals, 2 suprapygals, a pygal, 8 pairs of costals and 11 pairs of peripherals, but large amounts of variation are apparent in regard to the count of neural and suprapygal elements (Figure 2). The nuchal is typically a large, broad element and is characterized by the presence of riblike costiform processes that insert into peripheral III in crown chelydrids but are likely shorter in stem chelydrids. The neurals of most pan-chelydrids are broad and exhibit clear geometric shapes, but these elements are poorly defined and irregular in Chelydra spp. Suprapygal I is neural-like in its size and appearance, whereas suprapygal II is much broader and semilunate. The distal ends of the costal rib are broad and visible in ventral view below the peripherals. The bridge peripherals lack lateral keels and are therefore C-shaped in cross section. The bridge peripherals of stem chelydrids exhibit clear sockets for the peglike lateral processes of the plastron, but these are absent in crown representatives, as the bridge is fully ligamentous.

The carapace of pan-chelydrids is covered by a broad cervical, 5 hexagonal to rectangular vertebrals, 4 rectangular pleurals and 12 pairs of mar- ginals (Figure 2). The pleural/marginal sulcus mostly coincides with the costal/peripheral suture and is therefore mostly invisible in extant taxa with costal fontanelles (Figure 2). The extant Macrochelys temminckii is known to possess up to three consecutive supramarginals that are situated between pleurals I-III and marginals IV-IX, but their sulci mostly coincide once again with the costal fontanelles, and presence of these scutes is therefore not documented in osteological specimens (Figure 1B). Supramarginals have also been reported for Chelydropsis murchisoni, but I cannot confirm this observation based on the available evidence.

The plastron of pan-chelydrids is notably cruciform and reduced in size relative to the carapace. In basal pan-chelydrids, the plastron is solid, but many midline fontanelles are apparent in extant species (Figure 2). The plastron consists of an entoplastron and a pair of epi-, hyo-, hypo- and xiphiplastra. The anterior and posterior plastral lobes are generally subtriangular, but the anterior lobe is notably broadened and rectangular in Chelydropsis murchisoni. The epiplastra are straplike and broadly cover the lateral sides of the hyoplastra. In basal pan-chelydrids, the entoplastron is a kite-shaped element that fully fills the space between the epiplastra and hyoplastra; however, in extant forms, this element is reduced to the shape of an anchor, thereby revealing a gaping entoplastral fontanelle. The bridge of basal panchelydrids is relatively narrow, and the plastron articulates with peripherals III-VII through pegs and sutures. In extant chelydrids, by contrast, the bridge is greatly reduced and the plastron articulates through ligaments with peripherals IV-VII in Macrochelys temminckii or peripherals V-VII in Chelydra spp. (Figure 2). The xiphiplastra mirror the epiplastra by being straplike but exhibit a deeply notched area at the contact with the hypoplastra.

Hutchison and Bramble (1981) presented an insightful analysis regarding the homology of scutes in pan-kinosternoid turtles, but they did not apply their newly developed nomenclature to pan-chelydrids, likely because they presumed these two clades to only be distantly related. If one applies the rationale of Hutchison and Bramble (1981) to pan-chelydrids, one must conclude that the scutes lacking a midline contact are the abdominals, as in pan-kinosternoids; that the 
A

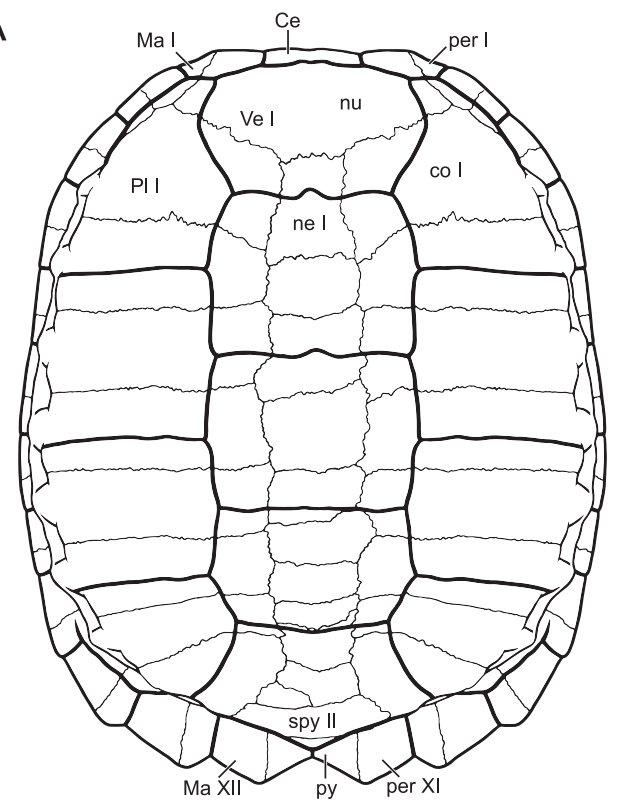

Chelydra serpentina

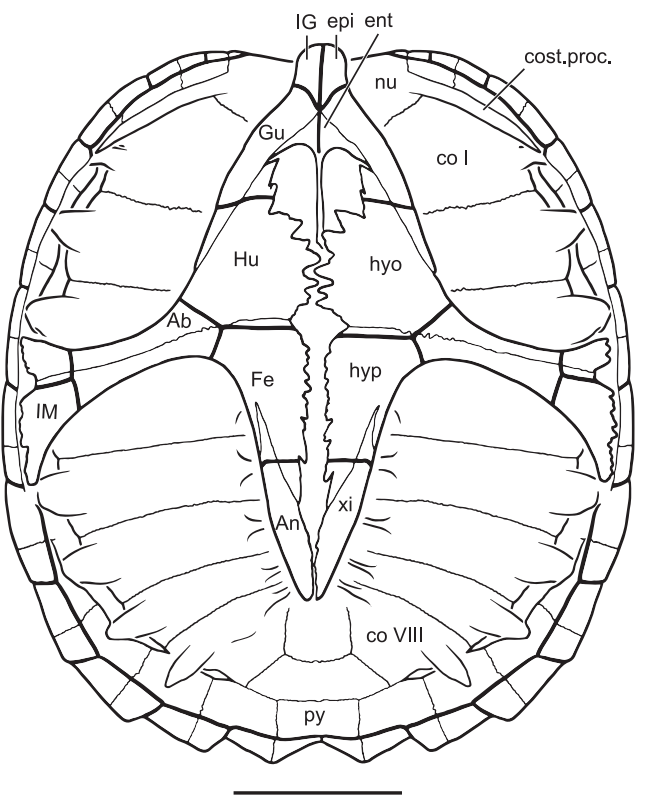

B

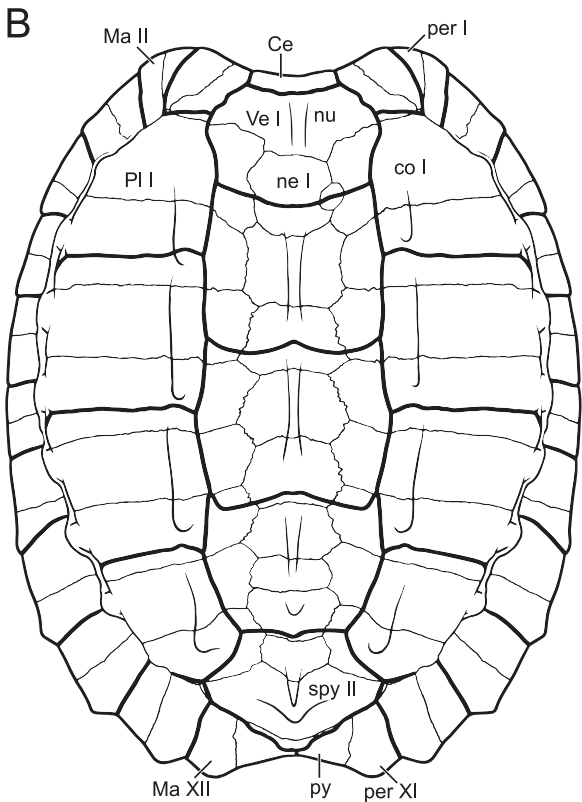

Macrochelys temminckii

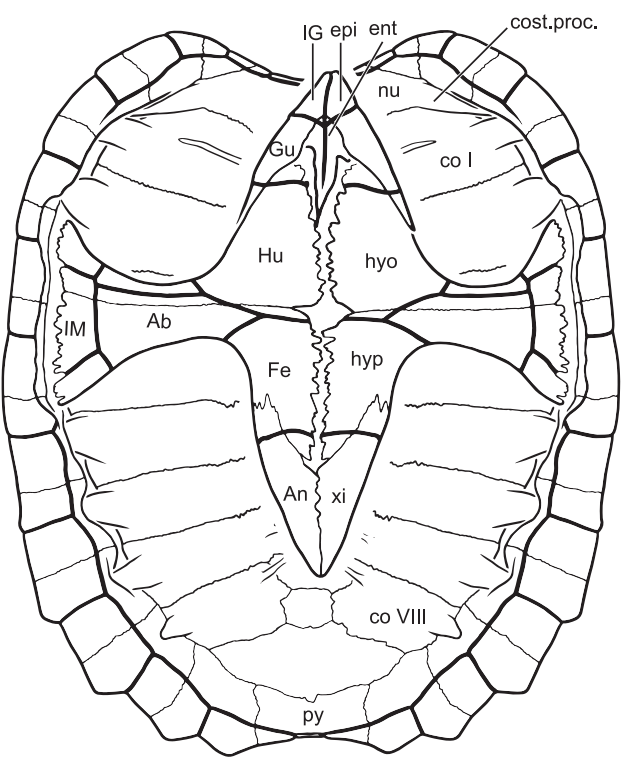

Figure 2. Shell morphology of Pan-Chelydridae as exemplified by two species. A, Chelydra serpentina (FMNH 8717). B, Macrochelys temminckii (UF 166146, holotype of M. suwanniensis Thomas et al., 2014). Abbreviations: $\mathrm{Ab}$, abdominal scute; An, anal scute; Ce, cervical scute; co, costal; cost. proc., costiform process; ent, entoplastron; epi, epiplastron; Fe, femoral scute; $\mathrm{Gu}$, gular scute; Hu, humeral scute; hyo, hyoplastron; hyp, hypoplastron; IG, intergular scute; IM, inframarginal scute; Ma, marginal scute; ne, neural; nu, nuchal; per, peripheral; Pl, pleural scute; py, pygal; spy, suprapygal; Ve, vertebrate scute; xi, xiphiplastron. Scale bar approximates $5 \mathrm{~cm}$. 
scutes mostly associated with the hyoplastra are the humerals, as in most turtles; and that the scutes associated with the epiplastra are the gulars, as in most other turtles. This implies that the pectorals are lost, as in pan-kinosternoids. All available pan-chelydrids have two pairs of gulars anterior to the humerals. It is possible that these represent ancestral gulars and extragulars in an arrangement reminiscent of some baenid turtles (Joyce and Lyson 2015). However, given that the loss of extragulars seems to be a synapomorphy of Durocryptodira, I here interpret these two structures as gulars and neomorphic intergulars that emerged in concert with the "epiplastral beak," a tonguelike anterior protrusion formed by the epiplastra. Pan-chelydrids, therefore, have a pair of intergulars, gulars, humerals, abdominals, femorals and anals (Figure 2), but large amounts of variation are apparent, as already noted by Meyer (1852). The abdominals universally lack a midline contact but are split into two elements in Macrochelys temminckii. Three pairs of inframarginals typically cover the lateral aspects of the bridge, but only two pairs are found in Chelydra spp.

\section{Postcranium}

Williams (1950) described the cervical anatomy of extant chelydrids in detail, but I am unaware of any systematic descriptions to the remaining skeleton. Chelydropsis decheni and Chelydropsis murchisoni are known from many articulated skeletons from Oligocene of Rott, Germany (Meyer 1854, 1865; Lydekker 1889), and the Miocene of Öhningen (Meyer 1845, 1852; Winkler 1869), Steinheim (Młynarski 1980b) and Unterwohlbach (Gaffney and Schleich 1994), Germany, respectively, but the available descriptions of the postcranial skeleton are generally brief in the corresponding literature.

The cervical column consists of eight vertebrae, and the cervical formula is typically $1((2((3((4)) 5)) 6\}\} 7)) 8)$. As in most durocryptodirans, the cervicals are low and broad, ribs are lacking, transverse process are places at the anterior end of the centrum, the posterior cervicals are well-developed ventral processes and cervical VIII possesses elongate and recurved postzygapophyses. The tail is notably elongate and adorned by well-developed chevrons. The anterior, procoelous caudals are separated from the posterior, opisthocoelous caudals by a single amphicoelous caudal, typically the third (Gaffney 1985). The coracoids are slightly expanded distally, and the glenoid lacks a distinct neck. The ilium is tilted slightly to the posterior, is straight and may show a minor hint of a thelial process midshaft. The lateral pubic and ischial processes are well developed. The thyroid fenestra is typically subdivided by the pubes, ischia and calcified cartilages. The epipubis is similarly present but typically consists of calcified cartilage. The hands and feet generally resemble those of most other durocryptodirans by being intermediate in length, having a phalangeal formula of 2-3-3-3-3 and having five claws in the hand but only four in the foot.

\section{Phylogenetic Relationships}

Thomas et al. (2014) recently highlighted that molecular data allow recognizing three populations of extant Macrochelys, with the population from the Suwannee River of Florida, USA, being sister to the remaining two populations from the Apalachicola and greater Mississippi drainage basins farther to the west. Whether these three populations should be regarded as three (Thomas et al. 2014), two (Folt and Guyer 2015) or one species (Turtle Taxonomy Working Group 2014) is currently under debate. I am unaware of a molecular study that investigates the three species of Chelydra, but it is reasonable to presume that the two taxa from Central and South America are each other's closest relatives.

The phylogenetic relationships of fossil panchelydrids remains poorly resolved. Gaffney (1975b) presented a phylogenetic analysis of five "pan-chelydrids", but this analysis is highly suboptimal using modern standards because the panchelydrid Protochelydra zangerli was presumed to be the outgroup, Platysternon megacephalum was presumed to be within the ingroup and an explicit matrix is lacking. The results of this analysis imply that the European Chelydropsis murchisoni (Macrocephalochelys pontica of Gaffney 1975b) is closer to Macroclemys temminckii than Chelydra serpentina, and therefore also a crown chelydrid.

Whetstone (1978a) provided a small analysis of the three species of Macrochelys he was aware of using cladistic arguments and hypothesized that M. auffenbergi and M. schmidti are the successive 


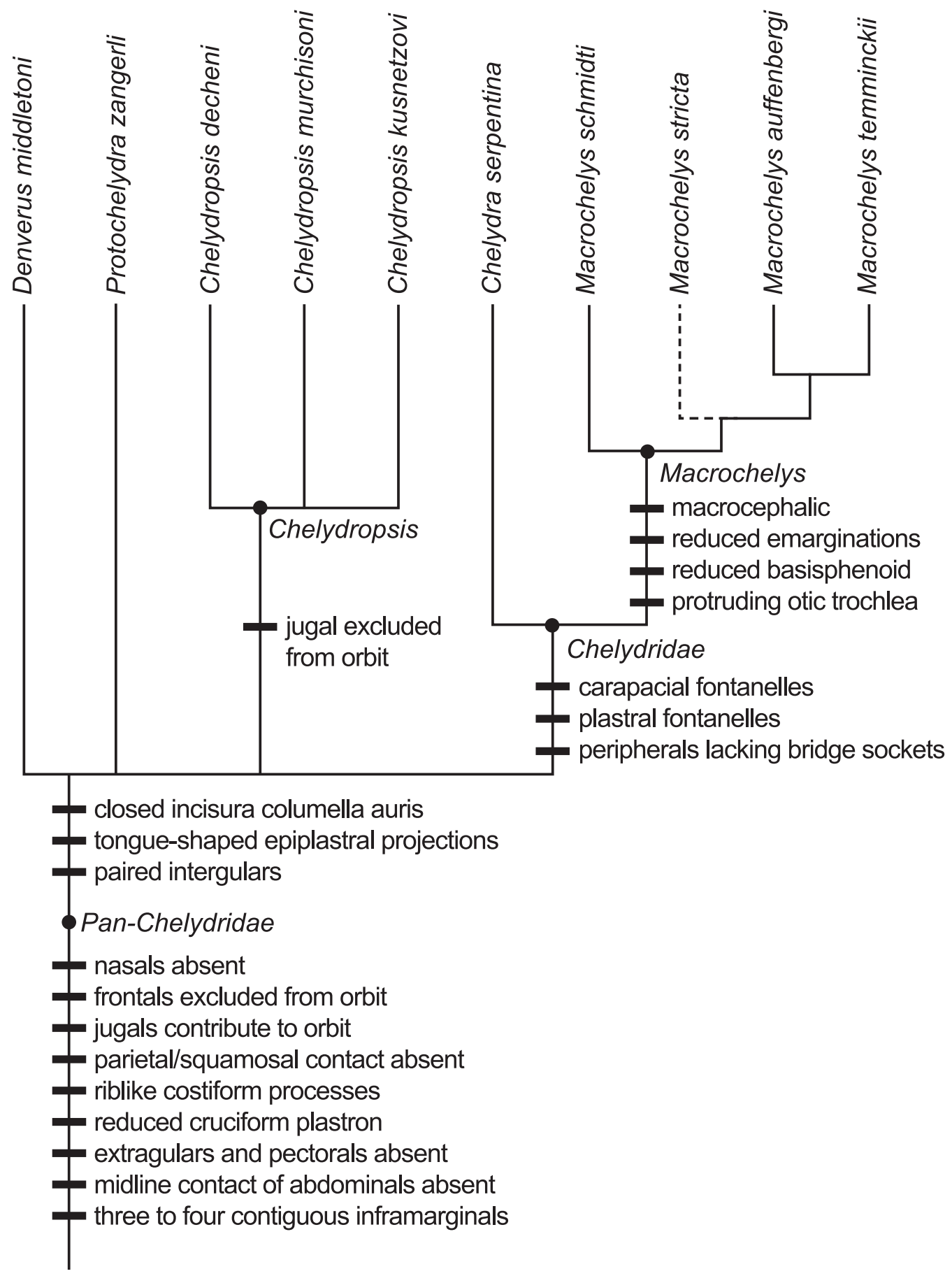

FIGURE 3. A phylogenetic hypothesis of valid pan-chelydrid taxa with select diagnostic characters for the most important clades. Given that a global phylogenetic analysis is still outstanding for the group, dashed lines highlight the ad hoc placement of fossils within the chelydrid crown group. The topology within Macrochelys follows the manual analysis of Whetstone (1978a). 
outgroups of $M$. temminckii. This topology incidentally corresponds with the appearance of these taxa in the fossil record, but this analysis too lacks rigorous testing.

Hutchison (2008) more recently presented a character/taxon matrix and a phylogenetic hypothesis for a selection of pan-chelydrid taxa but did not provide any of the parameters normally associated with parsimony analysis, such as the selection of an outgroup or use of ordered characters. As part of this study, I subjected the matrix to parsimony analysis but was not able to retrieve a tree with any resolution. Given a complete lack of alternative phylogenetic analyses, I utilize the highly reasonably topologies presented by Whetstone (1978a) for Macrochelys combined with Hutchison (2008) for Pan-Chelydridae (Figures 3 and 4) but await a more rigorous phylogenetic assessment in the future.

\section{Paleoecology}

All extant chelydrids are classified as aquatic bottom walkers (Zug 1971). Chelydra spp. inhabit all types of freshwater aquatic habitats, especially those with low energy, but will readily venture onto land in search of new habitat. Macrochelys temminckii, by contrast, prefers rivers with deeper water, and only females return to land to lay their eggs (Ernst and Barbour 1989). These two observations may explain the wide distribution of Chelydra from southeastern Canada to northern Colombia and the proclivity of Macrochelys to split into lineages that correspond to river drainage systems (Thomas et al. 2014). Fossil panchelydrids from the Late Cretaceous and Paleocene of North America are typically found in ponded environments (pers. obs.) and therefore seem to have been more ecological similar to extant Chelydra spp. by preferring bodies of water with low energy.

Whereas Chelydra spp. are true omnivores that actively seek prey, Macrochelys temminckii is a highly carnivorous ambush predator that lures prey into its mouth with its worm-shaped tongue (Ernst and Barbour 1989). The skulls of various fossil Macrochelys spp. with time increasingly resemble those of extant $M$. temminckii by being macrocephalic, having a notably midline "hook" and lacking broad triturating surfaces; it is therefore reasonable to infer similar dietary prefer- ences. The broad and flat triturating surfaces found in some individuals of Protochelydra zangerli (Erickson 2010) and Chelydropsis murchisoni (undescribed material housed at MNHN), by contrast, reveal that these basal pan-chelydrids were specialized molluscivores, similar to various baenids (Joyce and Lyson 2015), testudinoids (Joyce and Bell 2004) or bothremydids (Gaffney et al. 2006).

\section{Paleobiogeography}

The early record of pan-chelydrids is restricted to North America. Remains have been reported from as early as the Turonian to Utah, USA (Hutchison 1998), but these have not yet been figured or described; therefore, I cannot replicate this record. The oldest documented pan-chelydrids are cataloged fragments from the Santonian of Alberta, Canada (Brinkman 2003; Figure 5). Figured or cataloged fragments are otherwise known from the Campanian of Alberta (Brinkman 2003; Brinkman and Eberth 2006), Utah (Hutchison et al. 2013) and Coahuila, Mexico (Rodriguez-de la Rosa and Cevallos-Ferriz 1998), and from the Maastrichtian of Alberta (Brinkman 2003; Brinkman and Eberth 2006), Montana (Holroyd and Hutchison 2002; Holroyd et al. 2014), North Dakota (Holroyd and Hutchison 2002) and Wyoming (Holroyd and Hutchison 2002), USA. Other fragmentary remains reported from the Campanian of Coahuila (Brinkman and Rodriguez de la Rosa 2006) likely represent pankinosternoid remains instead (D.B. Brinkman, pers. comm., 2015). I agree with all previous authors that the Late Cretaceous material is undiagnostic at the species level and therefore refer it to Pan-Chelydridae (Figure 5).

Following the Cretaceous/Tertiary extinction event, the fossil record of pan-chelydrids improves dramatically throughout North America, though for unclear reasons (Figure 5). In addition to providing more undiagnostic material (Holroyd and Hutchison 2002; Holroyd et al. 2014), Early Paleocene (Puercan North American Land Mammal Age [NALMA], Danian) sediments in Colorado, USA, yielded skeletal remains of the small-bodied pan-chelydrid Denverus middletoni Hutchison and Holroyd, 2003. The significantly larger panchelydrid Protochelydra zangerli was originally reported from the Late Paleocene (Tiffanian 


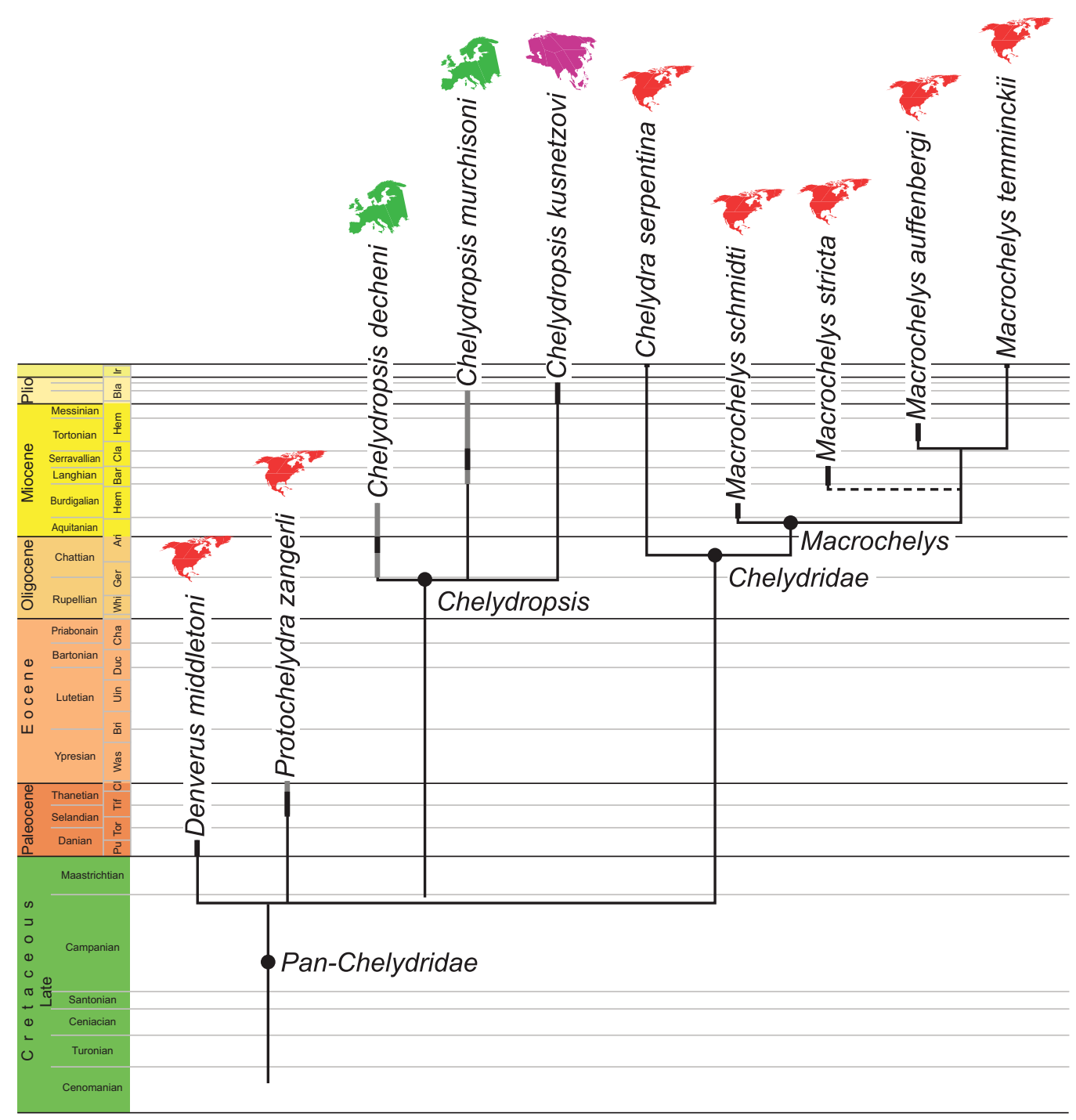

FIGURE 4. The stratigraphic and biogeographic distribution of valid pan-chelydrid taxa. Black lines indicate temporal distribution based on type material. Gray lines indicate temporal distribution based on referred material. The topology is a combination of those proposed by Whetstone (1978a) and Hutchison (2008).

NALMA, Selandian-Thanetian) of North Dakota (Erickson 1973, 1982, 1984, 2010) but has since been recovered from the Late Paleocene of Alaska, USA (Hutchison and Pasch 2004), and Alberta (Brinkman 2013). Bartels (1983) reported two complete shells of $P$. zangerli from the Late Paleocene of Wyoming, but figures are missing; therefore, I refer this material to Pan-Chelydridae. I furthermore agree that the holotype of Hoplochelys caelata Hay, 1908a is a chelydrid (e.g., Hutchison 2008) but find this taxon to be undiagnostic (see
Systematic Paleontology) and refer it to PanChelydridae as well. The Eocene record of PanChelydridae only consists of a few fragments from Wyoming (Holroyd et al. 2001) and Oregon, USA (Hanson 1996; Figure 5). Hutchison (2008) informally noted the presence of fragments from the Eocene of Ellesmere Island, Canada, but no specimens are referred. Eaton et al. (1999) similarly reported fragments from Utah, but these lack vouchers; therefore, I cannot replicate this claim. Hutchison (1992) finally reports chelydrids from 


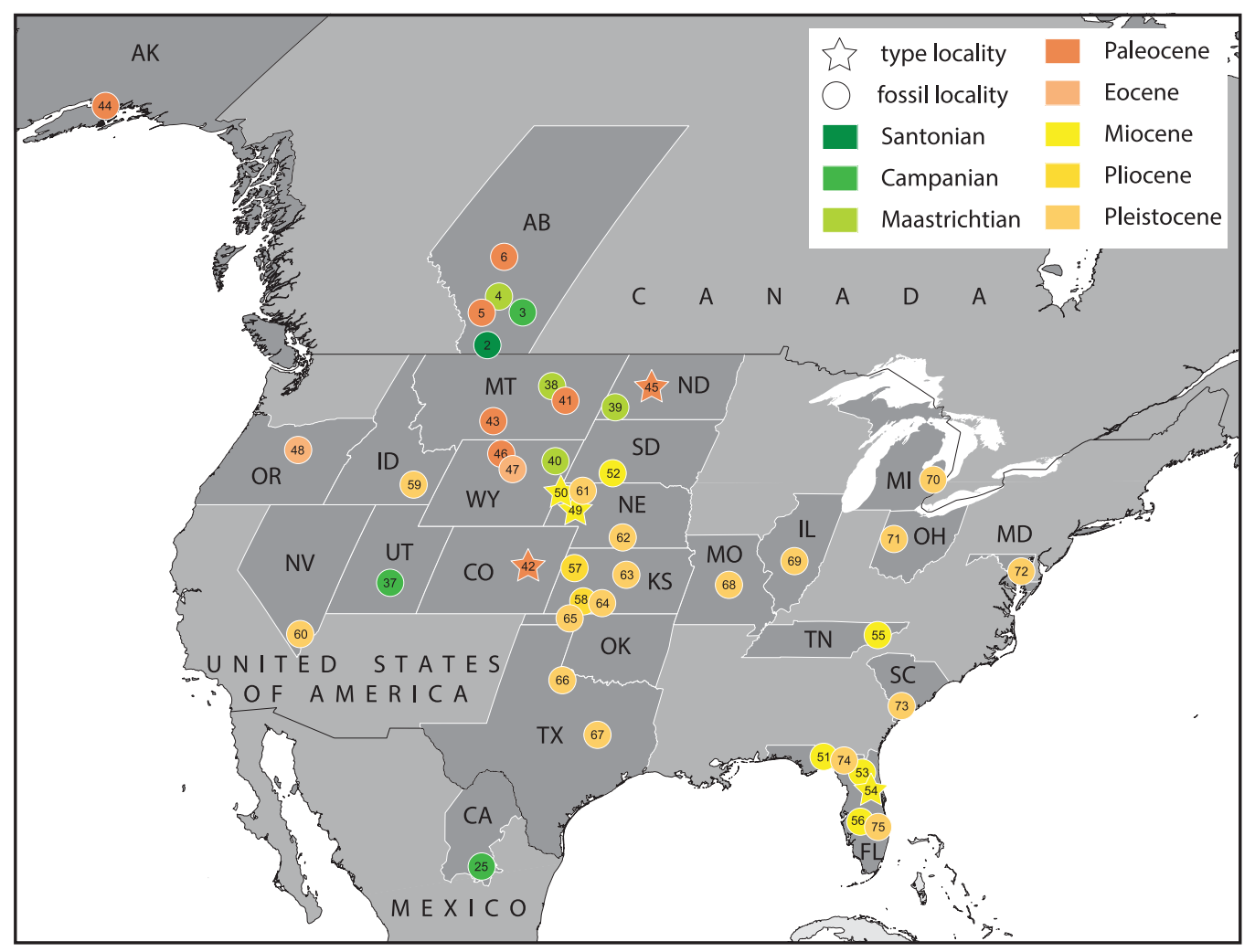

FIGURE 5. The geographic distribution of figured pan-chelydrids from North America. Stars mark the type localities of valid taxa. Locality numbers are cross-listed in Appendix 3. Abbreviations: AB, Alberta; AK, Alaska; CA, Coahuila; CO, Colorado; FL, Florida; ID, Idaho; IL, Illinois; KS, Kansas; MI, Michigan; MD, Maryland; MO, Missouri; MT, Montana; ND, North Dakota; NE, Nebraska; NV, Nevada; OH, Ohio; OK, Oklahoma; OR, Oregon; SC, South Carolina; SD, South Dakota; TN, Tennessee; TX, Texas; UT, Utah; WY, Wyoming.

the Oligocene of North America (Figure 5), but I once again cannot reproduce these claims, as no material is figured or listed. I agree with Hutchison (2008) that Acherontemys heckmani Hay, 1899 is not a pan-chelydrid (e.g., Hay 1908b), but rather a testudinoid.

The Neogene record of North American panchelydrids consists mostly of fragments, but some localities provide well-preserved skull remains, which document the emergence of the Macrochelys lineage. These include Macrochelys schmidti Zangerl, 1945 from the Early Miocene of Nebraska, USA (Zangerl 1945; Whetstone 1978a); Macrochelys stricta Matthew, 1924 from the Middle Miocene of Nebraska (Matthew 1924); and Macrochelys auffenbergi Dobie, 1968 from Late Miocene of Florida, USA, which includes extensive postcranial remains (Figure 5). Undetermined fragments referable to Macrochelys indet. are otherwise known from the Middle Miocene of Florida (Thomas et al. 2014); the Late Miocene of South Dakota, USA (Macrochelys temminckii of Zangerl 1945), and Florida (Thomas et al. 2014); the Pliocene of Kansas (Macroclemys temminckii of Hibbard 1963); and the Pleistocene of Texas, USA (Macrochelys temminckii of Hay 1911), and Florida (Auffenberg 1957; Thomas et al. 2014). Parmley (1992) reported fragmentary remains from the Late Miocene of Nebraska but did not provide figures to support this claim. Up to three species of Macrochelys that possibly diverged from one another in the Late Miocene currently inhabit large rivers across the southeastern United States (Thomas et al. 2014), but given current debates regarding the validity of all three taxa (e.g., Folt and Guyer 2015), I here recognize a single species, Macrochelys temminckii (Troost in Harlan 1835). 
The remaining Neogene pan-chelydrid record consists of rarely figured postcranial remains that have been referred to the Chelydra serpentina lineage (Figure 5). Given the broad distribution of Chelydra serpentina in North America today (Ernst 2008), it is plausible that these fragments indeed document a single lineage leading up to the extant species, but the available material is insufficient at present to allow reconstructing the sequential evolution of modern traits. Given that the early postcranial morphology of the Macrochelys lineage remains obscure, I herein refer all fragments from the Miocene to Chelydridae indet. These records include fossils from the Middle Miocene of Nebraska (Holman and Sullivan 1981) and from the Late Miocene of Florida (Bourque 2013; Thomas et al. 2014) and Tennessee, USA (Bentley et al. 2011). Given that the Macrochelys lineage is well established throughout the Miocene, I presume that fossils representing the Chelydra and Macrochelys lineage are more easily distinguishable by the Pliocene. I therefore refer all fragmentary material from the Plio/Pleistocene to Chelydra indet. This includes fragments from the Pliocene of Kansas (Hibbard 1934, 1939, 1963; Galbreath 1948) and from the Pleistocene of Idaho (Pinsof 1998), Nevada (Van Devender and Tessmann 1975), Nebraska (Preston 1979), Kansas (Galbreath 1948; Hibbard and Taylor 1960; Schultz 1965; Preston 1971, 1979; Holman 1972), Oklahoma (Preston 1979), Texas (Holman 1964), Missouri (Parmalee and Oesch 1972), Illinois (Holman 1966), Michigan (Wilson 1967), Ohio (Holman 1986), Maryland (Cope 1870; Hay 1908b) and South Carolina (Dobie and Jackson 1979). The only exceptions are rich skeletal remains of a large-bodied fossil chelydrid from the Pleistocene of Florida (Macrochelys floridana of Hay 1907; Chelydra floridana of Thomas et al. 2014), which I believe to broadly overlap in size and morphology with the extant Florida snapping turtles (pers. obs. of material at UF) and therefore refer to Chelydra serpentina. I herein do not list Holocene remains (see Ernst 2008 for a summary). Up to three species of Chelydra currently inhabit a broad land area from southeastern Canada to Colombia (Ernst 2008), but the dispersal event from North America to South America that occurred as part of the Great American Interchange has not yet been documented with fossils.
The early record of pan-chelydrids in Europe is somewhat obscured by the fragmentary nature of the available record and changing taxonomic assessments. Groessens-Van Dyck (1984) figured fragmentary remains from the Paleocene of Belgium, but I cannot confirm their pan-chelydrid identity, whereas others seem to have ignored these reports (e.g., Lapparent de Broin 2001; Danilov 2005). Additional fragments from the Paleocene of Belgium (Groessens-Van Dyck and Schleich 1988) are not figured, and their pan-chelydrid affinities cannot be confirmed either. Lapparent de Broin (2001) interprets various remains from the Cretaceous to Eocene of Europe as being "chelydroid" in nature, but given the vague definition of the term chelydroid, it is unclear to which clade she is referring. Lapparent de Broin (2001) nevertheless notes that these fragments lack derived "chelydrid" traits, and it is therefore safe to presume that these do not represent the clade Pan-Chelydridae, but perhaps another clade, such as Macrobaenidae (Danilov 2008). Lapparent de Broin (2001) mentions the presence of Pan-Chelydridae in the Late Eocene of France, but this record remains to be described or figured. Reinach (1900) finally reported a single pan-chelydrid costal fragment from the Early Oligocene of Germany, but this originates from marine sediments, and I see similarities with cheloniid sea turtles (contra Broin 1977) as the fragment in question is notably thick, displays a highly spongy internal structure and reveals the former presence of a strong rib head. It therefore seems all but certain that panchelydrids were not present in Europe until the Early Oligocene.

Some pan-chelydrid specimens have been reported from the Late Oligocene of France and Germany (Figure 6). Given that there is only evidence for a single lineage of pan-chelydrid in Europe, I here refer all undiagnostic material from France (see Broin 1977 for an extensive summary of French localities) and Germany (Karl et al. 2011) to Chelydropsis and otherwise only recognize one early taxon, Chelydropsis decheni, from France (Broin 1977) and Germany (Meyer 1852, 1854, 1865). Additional fragments have been reported from throughout Germany (Schleich 1988; Schleich and Groessens van Dyck 1988; Karl 1990), but I cannot confirm their specific identity with the available evidence. 


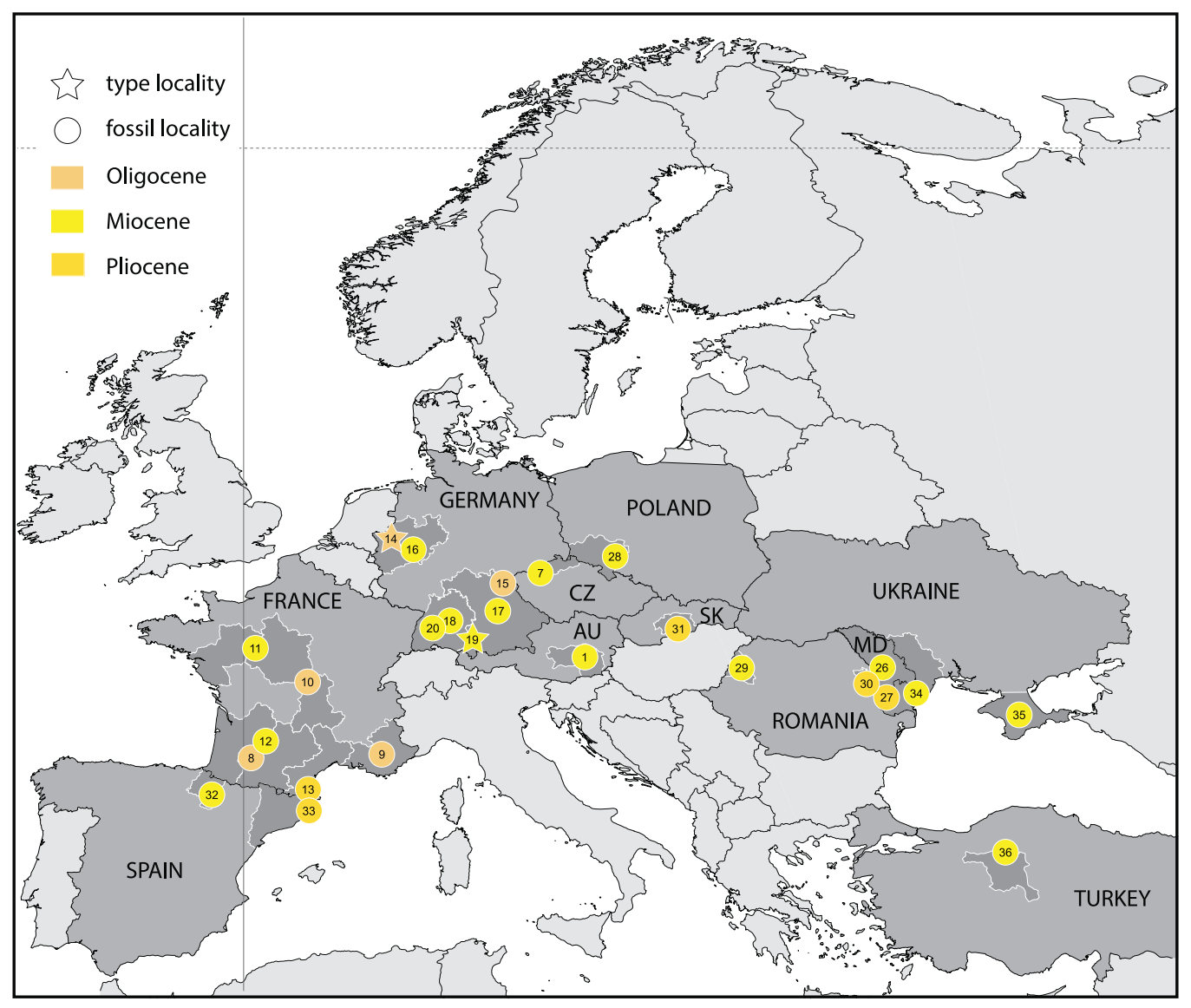

FIGURE 6. The geographic distribution of figured pan-chelydrids from Europe. Stars mark the type localities of valid taxa. Locality numbers are cross-listed in Appendix 3. Abbreviations: AU, Austria; CZ, Czech Republic; MD, Moldova; SK, Slovakia.

Miocene sediments across much of Europe have yielded beautifully preserved pan-chelydrid material, including many complete skeletons and crania (e.g., Bell 1836; Meyer 1845; Winkler 1869; Broin 1977; Mlynarski 1980b; Gaffney and Schleich 1994; Figure 6). As for all Miocene material, I assign all undiagnostic material to Chelydropsis sp., including remains from Austria (Böhme and Vasilyan 2014), the Czech Republic (Laube 1900, 1910; Schlosser and Hibsch 1902), France (see Broin 1977 for a detailed list of localities), Germany (Groessens-Van Dyck and Schleich 1985; Schleich 1986; Strauch 1990; Karl 2013), Moldova (Khosatzky and Redkozubov 1989), Romania (Mlynarski 1966), Ukraine (Khosatzky 1949, 1966, 1982; Chkhikvadze 1980) and, though not technically part of Europe, nearby Anatolia, Turkey (Paicheler et al. 1978). I here refer diagnostic early Miocene remains from Spain to
Chelydropsis decheni (Murelaga et al. 1999; Murelaga et al. 2002) and Middle to Late Miocene remains from Austria (Peters 1855, 1868, 1869; Gross 2002), France (Broin 1977; Lapparent de Broin 2000), Germany (Bell 1836; Meyer 1845, 1852; Winkler 1869; Fraas 1870; Fuchs 1939; Mlynarski 1980b; Schleich 1981; Gaffney and Schleich 1994; Klein and Mörs 2003), Poland (Mlynarski 1981a, 1981b) and Ukraine (Pidoplichko and Tarashchuk 1960; Tarashchuk 1971) to Chelydropsis murchisoni. Due to a lack of figures, I am unable to confirm the specific identity of additional fragmentary material from Austria (Teppner 1914, 1915), Germany (Schleich 1981, 1982, 1985) and Moldova (Khosatzky and Tofan 1970). As political boundaries have changed throughout the 20th century, it is worth noting that no panchelydrids have been reported from modern-day Hungary (contra Szalai 1934). 


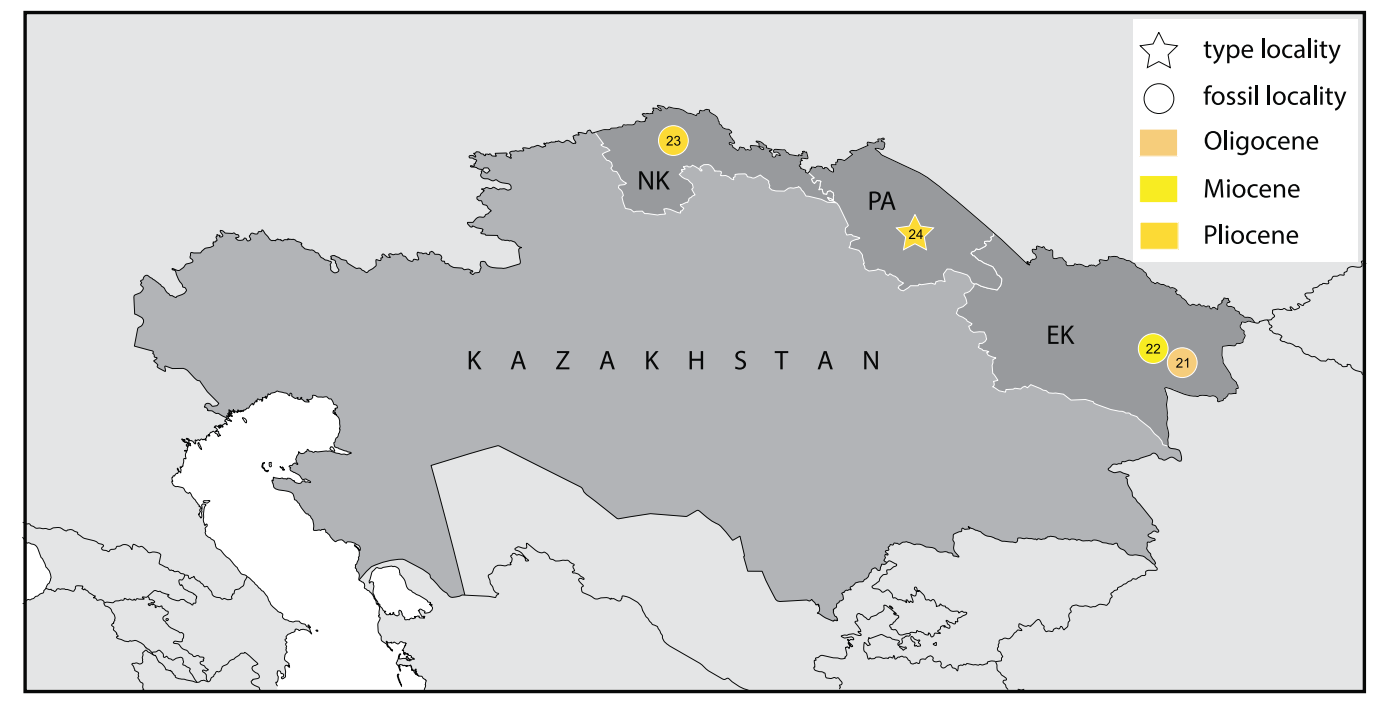

FIGURE 7. he geographic distribution of figured pan-chelydrids from central Asia. Stars mark the type localities of valid taxa. Locality numbers are cross-listed in Appendix 3. Abbreviations: EK, East Kazakhstan; NK, North Kazakhstan; PA, Pavlodar.

Although the Pliocene record is far less extensive, pan-chelydrids are present throughout Europe during this time period. I once again refer undiagnostic fossils to Chelydropsis indet., including material from France (Aymar 1992), Moldova (Khosatzky and Redkozubov 1986, 1989), Romania (Macarovici and Vancea 1959; Mlynarski 1969), Slovakia (Mlynarski 1963; Danilov et al. 2012) and Spain (Claude et al. 2014; Figure 6). The Ukrainian material mentioned previously is poorly dated but may be Pliocene as well. Pending better documentation, I disregard fragmentary material reported from Georgia (Syromyatnikova et al. 2013), Germany (Mörs 2002), Moldova (Khosatzky 1966), Slovakia (Młynarski 1963), Ukraine (Khosatzky 1966, 1982) and Russia (Syromyatnikova et al. 2013). Pan-chelydrids completely vanish from Europe by the Pleistocene, likely due to climatic cooling.

The Asiatic pan-chelydrid record is still poorly documented (Figure 7). Nessov (1987) reported the possible presence of pan-chelydrids from the Coniacian of Uzbekistan, but this claim was never further substantiated (Sukhanov 2000). Over the course of the past decades, many panchelydrid fragments have been reported from the Early Oligocene (Chkhikvadze 1971, 1973), Late Miocene (Chkhikvadze 1971, 1973) and Pliocene
(Khosatzky 1944, 1967, 1982; Gaiduchenko and Chkhikvadze 1985; Chkhikvadze 1987) of northeastern Kazakhstan. However, only a few fragments have been described or figured to date, and I am therefore only able to recognize one out of three named taxa, Chelydropsis kusnetzovi. I refer all other material once again to Chelydropsis indet.

Given that the early record of pan-chelydrids and pan-kinosternoids took place in North America, it seems all but certain that pan-chelydrids originated in situ in North America and secondarily dispersed to Europe and Asia. This conclusion contrasts earlier considerations of Chkhikvadze (1973), who derived pan-chelydrids in Asia from groups such as the Sinemydidae.

Hutchison (1998) hypothesized that panchelydrids originated in North America and migrated from North America to Europe in the Paleocene only to go extinct by the Eocene; however, as noted previously, the Paleocene panchelydrid record from Europe is dubious at best, and this hypothesis therefore lacks any basis. Instead, it seems that pan-chelydrids entered Eurasia only once (Hutchison 2000) at some point prior to the Late Oligocene. Given that the oldest records from Asia and Europe are nearly contemporary, it is not possible to distinguish the direction of migration. 


\section{Systematic Paleontology}

Valid Taxa

See Appendix 4 for the hierarchical taxonomy of Pan-Chelydridae as described in this work.

\section{Pan-Chelydridae Joyce et al., 2004}

Phylogenetic definition. Following Joyce et al. (2004), the term Pan-Chelydridae is herein referred to the total clade of Chelydridae (see Chelydridae below).

Diagnosis. Representatives of Pan-Chelydridae are currently diagnosed relative to other turtles by the symplesiomorphic absence of nasals, exclusion of the frontals from the orbit, inclusion of the jugals in the orbit, lack of a parietal/squamosal contact, presence of elongate costiform processes, a reduced, cruciform plastron, absence of extragulars and pectorals, lack of a midline contact of the abdominals, presence of three to four contiguous inframarginals, and the derived presence of an enclosed incisura columella auris, tongue-shaped epiplastral projections and paired intergulars (Figure 3).

\section{Chelydropsis Peters, 1868}

Type species. Chelydropsis carinata Peters, 1868

Diagnosis. Chelydropsis can be diagnosed as pan-chelydrid by the full list of characters given above for that taxon. Chelydropsis is currently differentiated primarily from other pan-chelydrids by the exclusion of the jugal from the orbit.

Comments. A series of well-preserved skeletons from the Germany localities of Öhningen and Rott were highly instrumental in the early phases of fossil turtle research, and they clearly revealed their pan-chelydrid affinities and faunal links between North America and Europe (Bell 1836; Meyer 1845, 1852). Although two species of extant chelydrids were known at the time, most early researchers do not seem to have been familiar with the newly described Macrochelys temminckii. They therefore only made comparisons with the abundantly known Chelydra serpentina (Linnaeus, 1758) and referred their new fossils to Chelydra. Peters (1868) noted systematic differences between new, beautifully preserved specimens from Austria and all previously described material and felt justified in naming of a new genus for his new species, Chelydropsis. His list of diagnostic characters includes the presence of a horizontally split nuchal, a double row of marginals, and well-defined neurals. I here agree with Williams (1952) and Mlynarski (1976) that the split nuchal of this taxon seems to be a taphonomic artifact, and I cannot find any clear evidence for the presence of supramarginals, here or elsewhere and despite claims to the contrary (e.g., Broin 1977; Hutchison 2008). Most diagnostic characters of Peters (1868) therefore lack a factual basis.

Zangerl (1945) noted that all known European pan-chelydrids seems to be distinct from the two extant North American taxa, but not until Chkhikvadze (1971) did it become common practice to unite all European material within Chelydropsis. Broin (1977) argued for the presence of two European species groups within Chelydropsis: the Oligo/Miocene decheni-sanctihenrici group and the Mio/Pliocene murchisoni group. Using the same characters, Chkhikvadze (1999) further emphasized the distinctness of these two groups by creating the taxon Chelydrasia for the decheni-sanctihenrici group, with the Asian Chelydropsis minax serving as the type species. Although some argued that Chelydrasia should be restricted to Asiatic forms to render a European Chelydropsis (e.g., Murelaga et al. 2002), others have followed the classification of Chkhikvadze (e.g., Hutchison 2008).

Although a rigorous phylogenetic analysis is still outstanding, I here only recognize a single lineage throughout the fossil record of Europe. Furthermore, the "decheni-sanctihenrici group" seems to be ancestral relative to the "murchisoni group." Although I agree that the development of Asiatic panchelydrids likely took place somewhat separately from those in Europe, it is most parsimonious to assume that they are related with European forms, although the available fossil evidence is far too fragmentary to allow testing this hypothesis at the moment. To avoid rendering Chelydropsis paraphyletic, I unite all Eurasian material into a single taxon, Chelydropsis.

Chelydropsis decheni (Meyer, 1852)

( $=$ Chelydropsis sanctihenrici Broin, $1977=$

Chelydropsis apellanizi Murelaga et al., 1999)

Taxonomic history. Chelydra decheni Meyer, 1852 (new species); Chelydra dacheni Młynarski, 1969 (incorrect spelling of species epithet); Chelydropsis decheni Broin, 1977 (new combination); Chelydrasia decheni Hutchison, 2008 (new combination).

Type material. IPB Ro4016 (holotype), a relatively complete skeleton on two slabs lacking the anterior tip of the skull, parts of the peripheral series and the posterior tip of the tail (Meyer 1852, pls. 18 and 19; Böhme and Lang 1991, fig. 1).

Type locality. Rott, North Rhine-Westphalia, Germany (Figure 6); Paleogene European Mammal Zone (MP) 30, Chattian, Late Oligocene (Aguilar et al. 1997).

Referred material and range. Late Oligocene (Chattian) of Rott (type locality), Germany (Meyer 1854, 1865; Lydekker 1889); Late Oligocene (Chattian) of the Department of Bouches-duRhône, France (type material of Chelydropsis sanctihenrici; Broin 1977); Early Miocene (Burdigalian) of Navarre, Spain (type material of Chelydropsis apellanizi; Murelaga et al. 1999; Murelaga et al. 2002).

Diagnosis. Chelydropsis decheni can be diagnosed as a representative of Chelydropsis by the isolation of the jugal from the orbit. Chelydropsis decheni is currently differentiated from Chelydropsis murchisoni by the presence of broader peripherals, a less serrated posterior carapacial margin, an anteroposteriorly wider bridge and a triangular anterior plastral lobe. Chelydropsis decheni is primarily distinguished from Chelydropsis kusnetzovi using temporal and biogeographic considerations (see Comments below)

Comments. Chelydropsis decheni is based on a relatively wellpreserved skeleton from the Late Oligocene of Rott, Germany 
(Meyer 1852). Although Meyer (1854, 1865) soon after described two additional skeletons from the type locality, no further material has been recovered ever since (Böhme and Lang 1991). Chelydropsis decheni can most readily be distinguished from the younger Chelydropsis murchisoni by its overall smaller size and the symplesiomorphic presence of a cruciform plastron with pointed anterior and posterior lobes, as opposed to the greatly broadened anterior plastral lobe of Chelydropsis murchisoni. The three available specimens from Rott are notable, as they represent differently sized juveniles with different ontogenetic stages (Meyer 1854, 1865).

More than 100 years after the description of Chelydropsis decheni, Broin (1977) documented new material from the Late Oligocene locality of Saint-Henri near Marseille in southern France. Broin (1977) highlighted many similarities between Chelydropsis decheni and the new French material but nevertheless decided to create a new taxon, Chelydropsis sanctihenrici, because the French material was larger, had a wider bridge, lacked fontanelles, had a less developed pygal notch and exhibited stronger carapacial ornamentation. However, Broin (1977) already noted that most of these characters could be related to ontogeny.

More recently, Murelaga et al. $(1999,2002)$ described new material from the Early Miocene (Burdigalian) of Navarre in northern Spain. Although the available material is highly fragmentary, it is apparent that this taxon exhibits the narrow cruciform plastron typical of Chelydropsis decheni and Chelydropsis sanctihenrici. Murelaga et al. (1999) furthermore diagnosed a new taxon, Chelydropsis apellanizi, based on nuanced differences in the thickness of the shell, the extent of the pygal notch and the relative length of the pectoral/abdominal sulcus compared with the femoral/abdominal sulcus. However, the fragmentary material available barely supports these observations.

Although the taxonomy of extant chelydrids is still far from resolved, it is apparent that chelydrids are not a speciose group. Among extant faunas, three species of Chelydra are currently recognized to occur in three distinct geographic areas throughout the Americas (Turtle Taxonomy Working Group 2014). Three distinct species of Macrochelys have similarly been recognized, but these, once again, occur in three nonoverlapping biogeographic areas (Thomas et al. 2014). Extant chelydrids therefore seem to diverge into separate lineages in response to allopatry, but the lack of extant species richness reveals that lineages typically converge when minor geographic barriers collapse. The only exception, apparently, is the permanent split between the Chelydra and Macrochelys lineages.

For much of the Tertiary, mainland Europe was fragmented by mountain ranges and epicontinental seas, but most of these barriers did not divide the continent completely and did not persists for much time. Although it is possible that European pan-chelydrids speciated in response to these geographic barriers, I find it intriguing that not a single European locality has yielded two sympatric pan-chelydrid taxa, in contrast to regularly occurring sympatric pan-trionychids, pantestudinids or pan-geoemydids (Lapparent de Broin 2001). Therefore, it is apparent that European pan-chelydrids never fully speciated as a response to barriers, as fully formed species should have lived in sympatry in some regions, at least for a period of time, after the collapse of geographic barriers.

Chelydropsis decheni and Chelydropsis sanctihenrici are nearly coeval (MP 30 compared with MP 26, respectively), and both occur within the northern Alpine foreland basin; I here interpret all documented differences to be related to ontogeny. Chelydropsis apellanizi is somewhat younger (Neogene European Mammal Zone [MN] 3) and occurs south of the rising Pyrenees in northern Spain, but the material is insufficient to rigorously distinguish it from its northern counterparts. I therefore group all three taxa into a single taxon, Chelydropsis decheni.

Fraas (1870) initially referred pan-chelydrid material from the Middle Miocene of Steinheim (MN 7+8), Germany, to Chelydropsis decheni; however, Mlynarski (1980b) transferred this material to the younger Chelydropsis murchisoni. I agree with that assessment. Myynarski (1963) similarly assigned fragmentary specimens from the Late Pliocene (MN 16) of Hajnáčka, Slovakia, to Chelydropsis decheni but later referred this material to Chelydropsis pontica (Mlynarski 1980a, 1980b). However, given the fragmentary nature of these remains, these are better interpreted as Chelydropsis indet. (Danilov et al. 2012). Additional pan-chelydrid material has been described from Oligocene to Early Miocene localities throughout Europe (see Appendix 3), but this material lacks the diagnostic characteristics of Chelydropsis decheni and is therefore herein assigned to Chelydropsis indet.

\section{Chelydropsis kusnetzovi Chkhikvadze in Gaiduchenko and Chkhikvadze, 1985}

Taxonomic history. Chelydropsis kusnetzovi Chkhikvadze in Gaiduchenko and Chkhikvadze, 1985 (new species).

Type material. IPGAS 6-1-3 (holotype), a partial carapace preserved in dorsal view (Gaiduchenko and Chkhikvadze 1985, unnumbered figure).

Type locality. Locality of Detskaya zheleznaya doroga (= Gusinyy perelet $=$ Pavlodar), Pavlodar Region, Kazakhstan (Figure 7); Koryakovskaya Svita (Formation), Early Pliocene (Gaiduchenko and Chkhikvadze 1985; Chkhikvadze 1987).

Referred material and range. Early Pliocene of Pavlodar Region (type locality), Kazakhstan (Gaiduchenko and Chkhikvadze 1985; Chkhikvadze 1987).

Diagnosis. Chelydropsis kusnetzovi can be diagnosed as a panchelydrid by the full list of shell characters given for that clade above. The placement of Chelydropsis kusnetzovi within Chelydropsis is here based purely on biogeographic considerations. Chelydropsis kusnetzovi is similar to the older Chelydropsis decheni in having a triangular anterior plastral lobe but differs from the coeval Chelydropsis murchisoni by lacking a rectangular anterior plastral lobe with broad epiplastra and a broad entoplastron.

Comments. In a series of papers, Chkhikvadze (1971, 1973, 1987) and Gaiduchenko and Chkhikvadze (1985) documented the presence of pan-chelydrids in Late Oligocene to Pliocene sediments in Kazakhstan and erected a total of three species: Chelydropsis minax, Chelydropsis poena and Chelydropsis kusnetzovi. The holotypes of the former two are isolated epiplastra (Chkhikvadze 1971), and subsequently referred rich material is insufficiently documented (Chkhikvadze 1973). I therefore dis- 
regarded these taxa as nomina dubia pending better description of the available material. In contrast to these two species, Chelydropsis kusnetzovi is based on a partial carapace, which, unfortunately, is only documented through a poorly executed illustration (Gaiduchenko and Chkhikvadze 1985) that cannot support a valid taxon either. However, Chkhikvadze (1987) soon after provided an unusually crisp photograph of a well-preserved, complete plastron. This specimen is interesting, as it has a narrow anterior plastral lobe, which replicates the symplesiomorphic morphology seen in Chelydropsis decheni, and not the wide anterior plastral lobe exhibited by coeval Chelydropsis murchisoni. It is therefore apparent that at least two plastral morphotypes were present in Eurasia during the Early Pliocene. I find this observation to be significant and therefore recognize the validity of Chelydropsis kusnetzovi. However, given how little material is described from Kazakhstan, I can only provide a meaningful diagnosis using a biogeographic rationale. It is therefore of utmost importance that the available material of Chelydropsis kusnetzovi be described in more detail.

Chelydropsis murchisoni (Bell, 1836)

(= Chelydra allingensis Fuchs, $1939=$ Chelydropsis carinata Peters, $1868=$

Chelydropsis murchisoni staeschei Mlynarski, $1980 \mathrm{~b}=$ Macrocephalochelys pontica

Pidoplichko and Tarashchuk, $1960=$ Trionyx sansaniensis Bergounioux, 1935)

Taxonomic history. Chelydra murchisoni Bell, 1836 (new species); Chelydropsis murchisoni Broin, 1977 (new combination); Chelydropsis murchisoni = Chelydra allingensis Mlynarski, 1980 b (senior synonymy).

Type material. BMNH 37204 (holotype), a near-complete skeleton preserved in ventral view (Bell 1836, pl. 24; Lydekker 1889).

Type locality. Öhningen (= Oeningen or Oehningen), BadenWürttemberg, Germany (Figure 6); MN 7+8, Serravallian, Middle Miocene (Aguilar et al. 1997).

Referred material and range. Early to Middle Miocene (Aquitanian-Langhian) of Pyrenees Basin, France (hypodigm of Chelydropsis sansaniensis of Broin 1977 and Lapparent de Broin 2000); Middle Miocene (Serravallian) of Molasse Basin, including Öhningen (type locality), Germany (Meyer 1845, 1852; Winkler 1869; Fuchs 1939; Schleich 1981; Gaffney and Schleich 1994; Karl 2013); Middle Miocene (Burdigalian/Langhian) of Styria, Austria (type material of Chelydropsis carinata; Peters 1855, 1868, 1869); Middle to Late Miocene (Langhian-Messinian) of the Lower Rhine Embayment, Germany (Klein and Mörs 2003); Middle Miocene (Serravallian) of the Steinheim Basin, Germany (Fraas 1870; Mlynarski 1980b); Middle Miocene (Serravallian) of Przeworno, Poland (Mlynarski 1981a, 1981b); Late Miocene/Early Pliocene of Odessa Oblast/Province, Ukraine (Pidoplichko and Tarashchuk 1960; Tarashchuk 1971); Late Miocene/Early Pliocene of Crimea (Tarashchuk 1971).

Diagnosis. Chelydropsis murchisoni can be diagnosed as a representative of Chelydropsis by the full list of characters given above for this taxon. Chelydropsis murchisoni is currently differentiated from Chelydropsis decheni and Chelydropsis kusnetzovi by the presence of narrower peripherals, more pronounced serration to the posterior carapacial margin, a narrower bridge and a broad anterior plastral lobe with broad epiplastra and a broad entoplastron.

Comments. Fossil turtles were reported as early as the beginning of the 19th century from the locality of Öhningen (Karg 1805), but the available description of a turtle of the name "Testudo orbicularis" is too vague to allow determining whether a fossil pan-chelydrid was already known at that time. The locality of Öhningen is commonly reported incorrectly as being located in Switzerland (e.g., Lydekker 1889; Młynarski 1976; Broin 1977), but in fact is located within the current borders of Germany (Holy Roman Empire until 1806, Grand Duchy of Baden of the German Confederation until 1871), though within sight of Switzerland. I see three possibilities for this persisting error. First, among other important finds, the locality of Öhningen is probably most famous for having yielded the complete skeleton of a human that was introduced to the world as homo diluvii testis [man who witnessed the biblical deluge] by Scheuchzer (1726) in the book Lithographia Helvetica, a title that alludes to Switzerland. The specimen in question actually represents a giant cryptobranchid salamander (Holl 1831). Second, given the proximity of Öhningen to the Swiss border, much important work on this locality was undertaken by Swiss paleontologists (e.g., Heer 1847-1853, 1862) and may therefore have created the impression that Öhningen was located in that country. Finally, Meyer (1852) correctly, though confusingly, described Öhningen as being located "at the northern border of Switzerland"'

Murchison (1832) reported a large turtle from Öhningen and noted that it reminded him of "Testudo indica." Bell (1832) concluded that the specimen was a fossil pan-chelydrid and soon after (Bell 1836) described and figured it under the name Chelydra murchisoni. A series of additional specimens of differing quality were later figured and described by Meyer (1845, 1852) and Winkler (1869). The holotype and at least two of the specimens figured by Winkler (1869) are now housed at the Natural History Museum in London (Lydekker 1889).

Broin (1977) presented good evidence to group all thenknown pan-chelydrid material from Europe into two species groups, the Late Oligocene to Early Miocene decheni/sanctihenrici group and the Middle Miocene to Early Pliocene murchisoni group (also see Chelydropsis decheni above). Mlynarski (1980a, 1980b) restricted the murchisoni group to the Middle Miocene and created the Late Miocene to Pliocene pontica group. I agree with Broin (1977) that many morphological differences exist between early and late representatives of European Chelydropsis, but material is currently insufficient to demonstrate the sequential acquisition of traits through time, although a general increase in size is apparent from the Late Oligocene to Late Pliocene. Given that not a single European locality has yielded two or more coeval pan-chelydrid species, I find it implausible to presume that European pan-chelydrids readily diversified into regional species but later never occurred in sympatry. I therefore presume that the European continent was inhabited by a single lineage that shows slow anagenetic change. As noted previously, Broin (1977) compiled sufficient morphological evidence to distinguish an early chronospecies 
(i.e., Chelydropsis decheni, her decheni/sanctihenrici group) from a late chronospecies (i.e., Chelydropsis murchisoni, her murchisoni group), but I find the Pliocene material too fragmentary to establish a third chronospecies as suggested by Mlynarski (1980a, 1980b) (see Lapparent de Broin 2000 for a similar opinion). Given that the skull, anterior plastral lobe and posterior carapacial margin are the most diagnostic, I attribute all fossil material from Europe to Chelydropsis decheni and Chelydropsis murchisoni only if they preserve these anatomical regions. All remaining European material is referred to Chelydropsis indet. based on biogeographic considerations. Using these criteria, Chelydropsis murchisoni is known from material ranging from the Middle Miocene to Late Pliocene of France, Germany, Poland and Ukraine (see complete list of referred material above).

Chelydropsis murchisoni is known from well-preserved cranial material from multiple localities (e.g., Pidoplichko and Tarashchuk 1960; Tarashchuk 1971; Broin 1977; Myynarski 1981a, 1981b; Gaffney and Schleich 1994), which differs from extant pan-chelydrids by having broad triturating surfaces well adapted to crushing hard-shelled prey such as bivalves, crustaceans and gastropods. Although there is a strange tradition within the pan-chelydrid literature to not figure fossil specimens in palatal view (e.g., Tarashchuk 1971; Mlynarski 1981a, 1981b; Erickson 2010), significant differences are nevertheless apparent in the relative size of triturating surfaces among material herein referred to Chelydropsis murchisoni, with specimens ranging from having relatively narrow (e.g., Gaffney and Schleich 1994) to extremely broad (e.g., undescribed material at $\mathrm{MNHN}$ ) triturating surfaces. Although these differences could be used to support the validity of multiple species, I once again assign this to interspecific variation, as extant molluscivorous turtles often show a great amount of variation in the relative size of their palates due to ontogeny (e.g., the trionychid Apalone ferox; Dalrymple 1977) or sexual dimorphism (e.g., representatives of Graptemys; Lindeman 2003).

\section{Denverus middletoni Hutchison and Holroyd, 2003}

Taxonomic history. Denverus middletoni Hutchison and Holroyd, 2003 (new species).

Type material. UCM 48400 (holotype), a partial shell consisting, among other fragments, of eight partial costals, three neurals, a partial suprapygal, left peripherals VI-VIII, right peripheral VII, left hyoplastron and right hypoplastron (Hutchison and Holroyd 2003, figs. 8 and 9).

Type locality. UCM locality 79013, El Paso County, Colorado, USA (Figure 5); Denver Formation, Puercan NALMA (Hutchison and Holroyd 2003), Danian, Early Paleocene (Woodburne 2004).

Referred material and range. Early Paleocene (Danian), Puercan NALMA, Denver Formation, El Paso County, Colorado, USA (Hutchison and Holroyd 2003).

Diagnosis. Denverus middletoni can be tentatively diagnosed (see Comments below) as a pan-chelydrid by the presence of a reduced, cruciform plastron; lack of a midline contact of the abdominals; three or four contiguous inframarginals; and the presence of a surface sculpturing consisting of fine plications. Among pan-chelydrids, $D$. middletoni is differentiated from Chelydropsis spp. and Protochelydra zangerli by the greater anteroposterior width of the bridge, by being distinctly tricarinate, and by termination of the inguinal buttress on peripheral VII. D. middletoni is differentiated from crown chelydrids by absence of plastral fontanelles, presence of sockets in the peripherals for articulation with the plastron and more extensive buttresses.

Comments. Denverus middletoni is based on a partial shell from the Early Paleocene of Colorado. Although the available material is highly fragmentary, this taxon can readily be distinguished from other early pan-chelydrids by its small size and from pankinosternoids by the thin nature of its plastron. However, it is not possible to rigorously diagnose this taxon as a pan-chelydrid, as it universally displays symplesiomorphic characters of Chelydroidea. I here follow Holroyd and Hutchison (2002) and Holroyd et al. (2014) by diagnosing this taxon as a pan-chelydrid by the presence of a surface texture consisting of fine plications.

\section{Protochelydra zangerli Erickson, 1973}

Taxonomic history. Protochelydra zangerli Erickson, 1973 (new species).

Type material. SMM P72.34.20 (holotype), a partial skull primarily lacking much of the right facial region (Erickson 1973, figs. 1-3).

Type locality. Wannagan Creek Quarry, NW 1/4, Section 18, T141N, R102W, Billings County, North Dakota, USA (Erickson 1973; Figure 5); Tongue River Formation, Tiffanian 4 NALMA (Erickson 2010), Thanetian, Late Paleocene (Woodburne 2004).

Referred material and range. Late Paleocene (DanianSelandian), type locality (Erickson 1973, 1982, 1984, 2010); Middle to Late Paleocene, Paskapoo Formation, southern Alberta (Brinkman 2013); Late Paleocene, Chickaloon Formation, Clarkforkian, Alaska (Hutchison and Pasch 2004).

Diagnosis. Protochelydra zangerli is diagnosed as a pan-chelydrid by the full list of characters provided for that clade above. Among pan-chelydrids, P. zangerli is differentiated from Chelydropsis spp. by the contribution of the jugal to the orbit and from Denverus middletoni in having a narrower bridge and lacking distinct carinae. $P$. zangerli is differentiated from chelydrids by absence of plastral fontanelles, presence of sockets in the peripherals for articulation with the plastron and more extensive buttresses.

Comments. The fossil locality of Wannagan Creek in North Dakota has yielded rich remains of the pan-chelydrid Protochelydra zangerli, including well-preserved cranial material (Erickson 1973, 1984, 2010), and its taxonomic validity is therefore uncontroversial. Fragmentary material has been referred to $P$. zangerli from the Campanian of Mexico (Rodriguez-de la Rosa and Cevallos-Ferriz 1998), the Maastrichtian of Montana and 
North Dakota (Holroyd and Hutchison 2002) and the Paleocene and Eocene of Wyoming (Bartels 1983; Holroyd et al. 2001); however, given that figured or detailed character analyses are lacking, I herein more carefully identify all of this material to Pan-Chelydridae indet. Well-preserved and well-figured material has been referred to this species from the Paleocene of Alaska (Hutchison and Pasch 2004) and Alberta (Brinkman 2013), and I agree with these taxonomic assessments. To allow future authors to more rigorously diagnose their material as belonging to $P$. zangerli, I urge the redescription of all available material from the type locality.

\section{Chelydridae Swainson, 1839}

Phylogenetic definition. Following Joyce et al. (2004), the name Chelydridae is herein referred to the clade arising from the last common ancestor of Chelydra serpentina (Linnaeus, 1758) and Macrochelys temminckii (Troost in Harlan, 1835).

Diagnosis. Representatives of Chelydridae are currently differentiated relative to more basal pan-chelydrids by the retention of costal and plastral fontanelles in skeletally mature individuals and by lacking pegs and sockets in the bridge.

\section{Macrochelys Gray, 1856}

Type species. Macrochelys temminckii (Troost in Harlan, 1835).

Diagnosis. Macrochelys can be diagnosed to be a representative of Pan-Chelydridae and Chelydridae by the full list of characters given for those clades above. Macrochelys can be distinguished from other chelydrids, notably Chelydra serpentina, by being strongly macrocephalic and having less well-developed upper and lower temporal emarginations, a reduced basisphenoid, a more strongly protruding processus trochlearis oticum, a broad nuchal notch, three rows of well-developed carapacial knobs, strong peripheral serrations, thickened peripherals, a more extensive bridge and a less developed epiplastral beak. The postcranial characters are currently only well known for M. temminckii and M. auffenbergi.

\section{Macrochelys auffenbergi Dobie, 1968}

Taxonomic history. Macroclemys auffenbergi Dobie, 1968 (new species); Macrochelys auffenbergi Hutchison, 2008 (new combination).

Type material. UF 10992 (holotype), a near-complete skeleton primarily lacking most of the skull (Dobie 1968, fig. 1a-c); UF 11053 (paratype), skull and mandible (Dobie 1968, fig. 1d); UF 9198, UF 9199 (paratypes), partial skulls (Dobie 1968, fig. 1d); UF 9242 (paratype), a partial shell; UF 9224-9228, UF 13051-13061 (paratypes), humeri (Dobie 1968, fig. 1b); UF 13062, UF 13063, UF 13064 (paratypes), proximal phalanges.

Type locality. McGehee Site, S 1/2, NW 1/4, Section 22, T9S, R17E, Alachua County, Florida, USA (Dobie 1968; Figure 5); early Hemphillian NALMA (Thomas et al. 2014), Tortonian, Late Miocene (Thomas et al. 2014).
Referred material and range. No specimens have been referred to date beyond the paratypes listed above. Thomas et al. (2014) report the presence of additional material of Macrochelys auffenbergi but do not figure specimens or provide catalog numbers.

Diagnosis. Macrochelys auffenbergi can be diagnosed to be part of Macrochelys based on the full list of characters given above for that clade. M. auffenbergi can be differentiated from $M$. schmidti by the presence of narrower pterygoids, laterally oriented eyes and more strongly hooked jaws; from $M$. stricta by having less well-developed lingual ridges; and from M. temminckii by being less macrocephalic, having better developed lingual ridges and having narrower triturating surfaces.

Comments. The Late Miocene McGehee Site in Florida has yielded a rich collection of beautifully preserved pan-chelydrid material, including skulls, shells and limb bones, which serves as the basis for Macrochelys auffenbergi, and the validity of this species has therefore never been controversial. Thomas et al. (2014) highlighted systematic differences between M. auffenbergi and all recent populations of Macrochelys, and it is therefore reasonable to speculate that this species is the immediate sister to all extant Macrochelys (Whetstone 1978a).

\section{Macrochelys schmidti Zangerl, 1945}

Taxonomic history. Macrochelys schmidti Zangerl, 1945 (new species); Macroclemys schmidti Williams, 1952 (new combination).

Type material. FMNH P26014 (holotype), a nearly complete skull (Zangerl 1945, figs. 2 and 3).

Type locality. East Clayton Quarry, Marsland, Dawes County, Nebraska, USA (Figure 5); Marsland Formation, early Hemingfordian NALMA (Zangerl 1945), Burdigalian, Early Miocene (Woodburne 2004).

Referred material and range. Early Miocene, type formation, Butte County, Nebraska (Whetstone 1978a).

Diagnosis. Macrochelys schmidti can be diagnosed as part of Macrochelys by the full list of cranial characters given for that taxon above. M. schmidti can be differentiated from all remaining Macrochelys by the symplesiomorphic retention of relatively wide pterygoids, dorsoventrally oriented eyes, more elongate jugals and lacking strongly hooked jaws.

Comments. Macrochelys schmidti is based on a small (basioccipital to tip of snout: $72 \mathrm{~mm}$ ), partially crushed skull from the Early Miocene of Nebraska (Zangerl 1945). Although Zangerl (1945) provided beautifully crafted stipple drawings of the type specimen, many anatomical details remain obscure. Whetstone (1978a) later referred a much larger and much better-preserved skull from the type formation of a neighboring county in Nebraska to this species, but a detailed description is missing for this well-preserved specimen as well. Much therefore remains unclear regarding the morphology of $M$. schmidti, and a revision is therefore long overdue. However, I agree in the list of systematic differences that Whetstone (1978a) provided to differentiate M. schmidti relative to other Macrochelys species. 
The species "Macrochelys schmidti" was recently included into the global phylogenies analysis of Sterli et al. (2013). The scoring is based on AMNH FAM11556, which is cataloged as a representative of that taxon. However, this specimen originates from the Middle to Late Miocene (Clarendonian NALMA) of Nebraska, not the Early Miocene (early Hemingfordian) of the same state; lacks the symplesiomorphic characteristics diagnostic of $M$. schmidti; and is therefore temporally and morphological much closer to M. stricta (see Macrochelys stricta below) but lacks the lingual ridges diagnostic of $M$. stricta. Although AMNH FAM11556 still demands formal description and evaluation, I nevertheless think it safe to assume that it does not represent $M$. schmidti.

\section{Macrochelys stricta (Matthew, 1924)}

Taxonomic history. Chelydrops stricta Matthew, 1924 (new species); Macrochelys stricta Hutchison, 2008 (new combination)

Type material. AMNH 6297 (holotype), a partial skull consisting mostly of the snout region (Matthew 1924, fig. 63).

Type locality. Snake Creek Beds, Sioux County, Nebraska, USA (Figure 5); Snake Creek Formation (Matthew 1924), Ogallala Group, Barstovian NALMA, Langhian-Serravallian, Middle Miocene (Woodburne 2004).

Referred material and range. No material has been referred to date.

Diagnosis. Macrochelys stricta can be diagnosed to be part of Macrochelys by being macrocephalic and lacking well-developed lower temporal emarginations. $M$. stricta can be differentiated from $M$. schmidti by the presence of narrower pterygoids, laterally oriented eyes and more strongly hooked jaws, and from $M$. auffenbergi and M. temminckii by exhibiting better-developed lingual ridges.

Comments. Macrochelys stricta is based on a partial skull consisting of the snout region of a large turtle from Nebraska and is intermediate in age between the Early Miocene M. schmidti and the Late Miocene M. auffenbergi. I agree with Hutchison (2008) that this species can be retained pending more detailed description and comparison with other taxa. The most compelling character that supports the validity of this species is the strong development of two lingual ridges.

\section{Invalid and Problematic Taxa}

\section{Broilia robusta Bergounioux and Crouzel, 1965 nomen dubium}

Taxonomic history. Broilia robusta Bergounioux and Crouzel, 1965 (new species); Broila robusta Bergounioux and Crouzel, 1965 (incorrect spelling); Chelydropsis sansaniensis = Broilia robusta (in part) = Leptochelys braneti Broin, 1977 (junior synonym); Hutchison, 2008 (lectotype designation).

Type material. MNHN SA uncat. (lectotype), a string of "caudal" vertebrae (Bergounioux and Crouzel 1965, fig. 6), a chimera composed of chelydrid caudals and mammalian cervicals (Broin 1977); MNHN SA uncat. (paralectotypes), elements from several specimens, including shell fragments and limb elements (Bergounioux and Crouzel 1965, figs. 10-15), a chimera composed of pan-chelydrid and pan-testudinid remains (Broin 1977; Hutchison 2008).

Type locality. Sansan, Department of Gers, France (Bergounioux and Crouzel 1965); MN 6, Langhian, Middle Miocene (Aguilar et al. 1997).

Comments. Broilia robusta is one of many taxonomic travesties created by Bergounioux (see Leptochelys braneti for another example). The species is typified based on an assemblage of specimens from the Miocene locality of Sansan, France (Bergounioux and Crouzel 1965), but later studies revealed this assemblage to be a chimera that includes pan-chelydrid, pantestudinoid and mammalian material (Chkhikvadze 1971; Broin 1977; Hutchison 2008). Hutchison (2008) attempted to resolve this issue by designating the caudal series as the lectotype, but this only partially resolved the issue, as Broin (1977) already demonstrated the caudal series to include mammalian cervicals in addition to pan-chelydrid caudals.

At this point, two possibilities remain to achieve nomenclatural stability: (1) designate a mammalian cervical as the "lectolectotype," thereby rendering this taxon irrelevant to the evolution of chelydrids; or (2) designate a single pan-chelydrid caudal as the "lectolectotype," thereby creating yet another poorly diagnosed pan-chelydrid taxon. Given that material from Sansan has already been used to typify up to four (!) panchelydrid taxa (see Emys sansaniensis Leptochelys braneti and Trionyx sansaniensis), of which Broilia robusta would at best been shown to be a junior synonym, I see no need to further resolve the taxonomic validity of this taxon and treat it as a nomen dubium.

\section{Chelydra allingensis Fuchs, 1939 nomen invalidum$$
\text { (= Chelydropsis murchisoni }[\text { Bell, 1836]) }
$$

Taxonomic history. Chelydra allingensis Fuchs, 1939 (new species); Chelydra allinghensis Williams, 1952 (incorrect spelling of species epithet); Chelydropsis murchisoni = Chelydra allingensis Mlynarski, 1980b (junior synonymy); Chelydropsis allingensis Schleich, 1981 (new combination).

Type material. BSPG LI 118 (syntype), partial shell consisting of nuchal, two peripherals, two costals and a cervical vertebra; BSPG LI 128 (syntype), partial left carapace; BSPG LI 129 (syntype), right femur; BSPG LI 322 (syntype), right epiplastron; BSPG LI 592 (syntype), left partial hyoplastron in articulation with neighboring peripherals; BSPG LI 593 (syntype), partial skull? and girdle remains; BSPG LI 594 (syntype), six articulated costals and peripherals; BSPG LI 595 (syntype), articulated carapace fragments; BSPG LI 651 (syntype), our peripherals and shattered scapulacoracoid (parts figured in Fuchs 1939, fig. 26).

Type locality. Viehhausen, Bavaria, Germany; MN 5, Burdigalian/Langhian, Early/Middle Miocene (Aguilar et al. 1997). 
Comments. Chelydra allingensis is based on a collection of fragments retrieved from the Miocene locality of Viehhausen (Fuchs 1939). The syntype series was originally housed in the collections of the University of Würzburg but was recently transferred to BSPG. Given that the old numbering system does not correspond to the new numbering system, I here only provide the new BSPG numbers. Fuchs (1939) originally diagnosed this taxon relative to other chelydrids based on nuances to the proportions of the carapacial and plastral scutes, but I find the material, in particular the expanded epiplastron, to fully overlap in its morphology with Chelydropsis murchisoni, which is typified by only slightly older material from nearby Öhningen, Germany.

\section{Chelydra argillarum Laube, 1900 nomen dubium}

Taxonomic history. Chelydra argillarum Laube, 1900 (new species).

Type material. SNSD-MMG CsT 611 (holotype), poorly preserved partial skeleton of a juvenile on a single slab of rock (Laube 1900, pl. 3.3).

Type locality. Břešt’any (= Preschen) near the town of Bílina (= Bilin), Ústecký Region, Czech Republic; MN 3, Burdigalian, Early Miocene (Aguilar et al. 1997).

Comments. Chelydra argillarum is based on a juvenile specimen recovered from sediments exposed in modern-day Czech Republic. As already indicated by Laube (1900), the type specimen was deposited in collections in Dresden, Germany, and I was able to confirm their current whereabouts at SNSD-MMG. Given that juvenile turtles, including this specimen, have poorly ossified shells, it is generally imprudent to use them to typify species. I therefore regard this taxon to be a nomen dubium.

\section{Chelydra laticarinata Hay, 1916 nomen invalidum \\ (junior synonym of Chelydra serpentina [Linnaeus, 1758])}

Taxonomic history. Chelydra laticarinata Hay, 1916 (new species); Chelydra osceola $=$ Chelydra laticarinata Richmond, 1958 (junior synonym); Chelydra serpentina $=$ Chelydra laticarinata Weigel, 1962 (junior synonym).

Type material. USNM V8827 (holotype, formerly FGS 7094), an isolated left peripheral VI (Hay 1916, pl. 6.6, 7)

Type locality. Vero, Saint Lucie County, Florida, USA; Pleistocene (Hay 1916).

Comments. Chelydra laticarinata and Chelydra sculpta (see Chelydra sculpta below) are based on isolated peripherals that were found in poorly dated Pleistocene deposits in Florida. Weigel (1962) suggested that these taxa may be synonymous with Chelydra serpentina, but Richmond (1958) and Feuer (1971) more precisely suggested them to be synonymous with the extant Florida snapping turtle Chelydra osceola Stejneger, 1918. How- ever, given that the names laticarinata and sculpta precede osceola, Smith et al. (1983) petitioned the International Commission on Zoological Nomenclature (ICZN) to suppress both in favor of osceola, a request soon after granted by the ICZN (1986). Given that osceola shows gradation toward the main population of serpentina farther to the north (e.g., Feuer 1971), this taxon is currently considered to be a subspecies of the latter. I therefore consider laticarinata and sculpta to be regular junior synonyms of serpentina, as otherwise suggested by Ernst (2008).

\section{Chelydra sculpta Hay, 1916}

nomen invalidum

(junior synonym of Chelydra serpentina [Linnaeus, 1758])

Taxonomic history. Chelydra sculpta Hay, 1916 (new species); Chelydra osceola = Chelydra sculpta Richmond, 1958 (junior synonym); Chelydra serpentina $=$ Chelydra sculpta Weigel, 1962 (junior synonym).

Type material. USNM V8826 (holotype, formerly FGS 5510), an isolated right peripheral IX (Hay 1916, pl. 6.8, 9).

Type locality. Vero, Saint Lucie County, Florida, USA; Pleistocene (Hay 1916).

Comments. See Chelydra laticarinata (above).

\section{Chelydropsis apellanizi Murelaga et al., 1999 nomen invalidum \\ (junior synonym of Chelydropsis decheni}

[Meyer, 1852])

Taxonomic history. Chelydropsis apellanizi Murelaga et al., 1999 (new species); Chelydrasia apellanizi Hutchison, 2008 (new combination).

Type material. UPV/EHU BF 58 (holotype), a left hyoplastron (Murelaga et al. 1999, fig. 2c, d); UPV/EHU BF 19, left peripheral X, UPV/EHU BF 20, right peripheral IX, UPV/EHU BF 21, pygal, UPV/EHU BF 23, neural I, UPV/EHU BF 64, right hypoplastron, UPV/EHU BF 74, neural, UPV/EHU BF 113, right xiphiplastron, UPV/EHU BF 131, partial left epiplastron (paratypes) (Murelaga et al. 1999, figs. 1a-j and 2a, e-h).

Type locality. Barranco del Fraile site, Bardenas Reales, Navarre, Spain; MN 3, Burdigalian, Early Miocene (Murelaga et al. 1999).

Comments. Early Miocene outcrops at the Barranco del Fraile site in northern Spain have yielded a total of 21 chelydrid fragments, which have served as the basis of Chelydropsis apellanizi (Murelaga et al. 1999; Murelaga et al. 2002). Although I agree that the taxon was attributed to the decheni-sanctihenrici group of Broin (1977), I am less convinced by its diagnosis as a distinct taxon, given that the proposed differences are more reasonably attributed to ontogenetic variation. For an extensive justification, see Chelydropsis decheni (above).

Together with material from Turkey (Paicheler et al. 1978), fossil pan-chelydrids from Spain are notable, as they are 
the only specimens known from south of the greater Alpine/Himalayan mountain chain that runs throughout Europe and Asia. At this point, however, I find this observation insufficient to diagnose a valid taxon using geographic considerations.

$$
\begin{gathered}
\text { Chelydropsis carinata Peters, } 1868 \\
\text { nomen invalidum } \\
(=\text { Chelydropsis murchisoni [Bell, 1836]) }
\end{gathered}
$$

Taxonomic history. Chelydropsis carinata Peters, 1868 (new species); Chelydropsis carinatus Mlynarski, 1976 (incorrect spelling of species epithet).

Type material. Unknown location (holotype), a relatively complete carapace (Peters 1869, pl. 1). See Comments below regarding whereabouts of holotype.

Type locality. Coal seam von Eibiswald, Steyeregg, or Wies, Styria, exactly locality not provided (Peters 1868, 1869); MN 5 , Burdigalian/Langhian, Early/Middle Miocene (Aguilar et al. 1997).

Comments. Peters first described fossil turtle material from Styria, Austria, under the name Chelydra sp. (Peters 1855), then under the new name Chelydropsis carinata (Peters 1868); finally, he provided a beautiful figure of the well-preserved type specimen, which consists of a nearly complete, large carapace (Peters 1869). Peters (1868) primarily diagnosed his taxon relative to other then-known chelydrids by the presence of a horizontally split nuchal, a double row of marginals and well-defined neurals. Williams (1952) and Mlynarski (1976) already noted that the split nuchal is a taphonomic artifact, and I agree with this assessment. Peters's (1869) beautiful figure of the holotype furthermore does not evidence the presence of supernumerary marginals, but rather deep plications that partially divide the bridge marginals. The general morphology of Chelydropsis carinata, including the well-defined neurals, otherwise overlaps fully with that of Chelydropsis murchisoni; therefore, I synonymize these taxa with confidence.

Peters (1868) was correct in noting for the first time that European fossil chelydrid material varied systematically from extant North American taxa, and he created a new genus name to accommodate this observation. However, because all subsequent authors thought the presence of two nuchals to be an essential characteristic of Chelydropsis, newly named European taxa were still routinely assigned to the North American Chelydra (Laube 1900; Fuchs 1939; Schmidt 1966). Not until Chkhikvadze (1971) were all Eurasian taxa united under the name Chelydropsis.

Peters $(1868,1869)$ reported that the holotype was housed in the private collections of Letocha in Vienna, but I cannot find any references to this specimen in the literature from a later time. This specimen was not listed in a recent review of Austrian turtle (Gemel and Rauscher 2000) or in the list of turtles held in Graz (Gross 2002). I was able to furthermore clarify that it is currently neither held at the Naturhistorisches Museum Wien (= Natural History Museum) nor at the Geologische Bundesanstalt (= Federal Geological Survey of Austria). The whereabouts of this specimen are therefore currently unknown.

\section{Chelydropsis minax Chkhikvadze, 1971 nomen dubium}

Taxonomic history. Chelydropsis minax Chkhikvadze, 1971 (new species); Chelydrasia minax $=$ Chelydrasia poena Mlynarski, 1976 (junior synonym); Chelydrasia minax Chkhikvadze, 1999 (new combination).

Type material. IPGAS Z-35-25 (holotype), an isolated right epiplastron (Chkhikvadze 1971, fig. 1a).

Type locality. Tayzhuzgen ("Cherepakhovoe pole"), Zaisan Basin, East Kazakhstan, Kazakhstan; Kustovskaya Svita (Formation), Lower Oligocene (Chkhikvadze 1971).

Comments. Chkhikvadze (1971) reported fossil turtle material from the Tertiary Zaisan Basin of eastern Kazakhstan, which included the first known chelydrid material from the Asian continent. Of this material, Chkhikvadze (1971) figured and described two isolated epiplastra from the Lower Oligocene and Late Miocene under the names Chelydropsis minax and Chelydropsis poena, respectively. In his review of the turtles of the Zaisan Basin, Chkhikvadze (1973) soon after referred up to 400 fragments to this species, of which he figured about a dozen, which unambiguously confirm the presence of pan-chelydrids at this locality but, in my opinion, added little to their anatomy. The most notable feature that is apparent from this material is the presence of narrow epiplastra, a symplesiomorphic feature found among all pan-chelydrids.

It is notable that central Asia was partially to fully separate from Europe throughout much of the early Tertiary, and it is implausible that much genetic exchange took place across the existing oceanic barriers (Popov et al. 2004). However, the presence of plausible biogeographic barriers is not sufficient to support the validity of a fossil taxon. I therefore consider Chelydropsis minax and Chelydropsis poena to be undiagnostic and await the description of more comprehensive collections.

\section{Chelydropsis staeschei Mlynarski, 1980b nomen invalidum \\ (= Chelydropsis murchisoni $[$ Bell, 1836])}

Taxonomic history. Chelydropsis murchisoni staeschei Mlynarski, 1980b (new subspecies).

Type material. SMNS 50142 (holotype), a partial skeleton, including broken skull, mandible, anterior cervical vertebrae, shell and long bones (Myynarski 1980b, figs. 8 and 11, pls. 2b, c and $3 \mathrm{a}, \mathrm{d})$.

Type locality. Steinheim, Baden-Württemberg, Germany (Mlynarski 1980b); MN 7/8, Serravallian, Middle-Miocene (Aguilar et al. 1997).

Comments. Mlynarski (1980b) provided a comprehensive description of Chelydropsis murchisoni material from the Steinheim meteorite basin in southern Germany and noted systematic differences with material from other localities that he 
utilized to create a new subspecies, Chelydropsis murchisoni staeschei, as opposed to Chelydropsis murchisoni murchisoni from the type locality of Öhningen, Germany. Following the rules of the ICZN (1999), a subspecies name is considered equivalent to a species name, and I am therefore obliged to list this taxon in this contribution. However, given that I see no utility of utilizing subspecies names, I herein simply consider staeschei to be synonymous with murchisoni.

\section{Chelydropsis poena Chkhikvadze, 1971 nomen dubium}

Taxonomic history. Chelydropsis poena Chkhikvadze, 1971 (new species); Chelydrasia minax = Chelydrasia poena Mlynarski, 1976 (junior synonym); Chelydrasia poena Hutchison, 2008 (new combination).

Type material. IPGAS Z-61-1 (holotype), an isolated left epiplastron (Chkhikvadze 1971, fig. 1b).

Type locality. Ashutas ("Kaymanovaya cherepakha"), Zaisan Basin, East Kazakhstan, Kazakhstan; Zhamangorinskaya Svita (Formation), Late Miocene (Chkhikvadze 1971).

Comments. See Chelydropsis minax (above).

\section{Chelydropsis sanctihenrici Broin, 1977 nomen invalidum \\ (junior synonym of Chelydropsis decheni}

[Meyer, 1852])

Taxonomic history. Chelydropsis sanctihenrici Broin, 1977 (new species); Chelydrasia sanctihenrici Chkhikvadze, 1999 (new combination).

Type material. UL1 92837 (holotype), partial carapace lacking most of the right peripheral series and the right distal costals (Broin 1977, fig. 37, pl. 35.3).

Type locality. Saint-Henri, Marseille, Department of Bouchesdu-Rhône, France; MP 26, Chattian, Late Oligocene (Aguilar et al. 1997).

Comments. Chelydropsis sanctihenrici is based on a small assortment of specimens collected from Late Oligocene sediments near the city of Marseille, France. Broin (1977) provided an excellent description of this material, including detailed figures, and the morphology of this taxon is therefore well characterized. Although Broin (1977) noted great similarities between Chelydropsis sanctihenrici and Chelydropsis decheni, she nevertheless felt justified to name a new species based on differences in size, the extent of the bridge and the presence of sculpturing, characters she readily admitted to perhaps be related to ontogenetic differences, as Chelydropsis decheni is mostly known from small, perhaps juvenile skeletons. Given that the close temporal and spatial proximity of both taxa, I here interpret these minor differences as regular interspecific variation and consider Chelydropsis sanctihenrici to be a nomen invalidum (see Chelydropsis decheni above).

\section{Chelydra strausi Schmidt, 1966 nomen dubium}

Taxonomic history. Chelydra strausi Schmidt, 1966 (new species); Chelydropsis (formerly Trionyx) nopcsai $=$ Chelydra strausi $=$ Macrocephalochelys pontica $=$ Testudo grandis Chkhikvadze, 1980 (junior synonym); Chelydropsis (formerly Trionyx) nopcsai $=$ Chelydra strausi Karl et al., 2012 (junior synonym).

Type material. GPIG/GZG W05873a (holotype), near-complete juvenile specimen (Schmidt 1966, fig. 1; Karl et al. 2012, fig. 1c).

Type locality. Willershausen, Lower Saxony, Germany (Schmidt 1966); MN 16/17, Piacenzian/Gelasian, Plio/Pleistocene (Aguilar et al. 1997).

Comments. Chelydra strausi is based on a relatively complete skeleton of a hatchling pan-chelydrid with a total body length of approximately $70 \mathrm{~mm}$. Considering its small size, the specimen is surprisingly well preserved; however, most of the bones are not yet ossified, and the specimen therefore displays only few osteological details. Although some previous authors attempted to synonymize this taxon with others (e.g., Chkhikvadze 1980; Karl et al. 2012), I find it futile to evaluate the taxonomic identity of juvenile turtles. I therefore regard this taxon to be a nomen dubium.

\section{Emys sansaniensis Lartet, 1851 nomen dubium}

Taxonomic history. Emys sansaniensis Lartet, 1851 (new species).

Type material. Unknown.

Locality. Sansan, Department of Gers, France (Lartet 1851; Figure 5); MN 6, Langhian, Middle Miocene (Aguilar et al. 1997).

Comments. Lartet (1851) named a total of six fossil turtle taxa in his pioneering study on the Miocene fauna of Sansan, France, but he did not explicitly list any specimens or provide illustrations, making it near impossible to fully reproduce his taxonomic assignments. The brief taxonomic descriptions of Lartet (1851) highlights that Emys sansaniensis was a large turtle reaching a carapace length of up to $45 \mathrm{~cm}$. Given that pan-chelydrids are the only known turtles to reach this size at Sansan, Broin (1977) reasoned that E. sansaniensis may represent a pan-chelydrid, but she also stressed that this rationale is highly speculative and that this taxon should be removed from taxonomic consideration. I fully agree with this assessment.

\section{Emysaurus meilheuratiae Pomel, 1846 nomen dubium}

Taxonomic history. Emysaurus meilheuratiae Pomel, 1846 (new species); Chelydra meilheuratiae Maack, 1869 (new combination); Chelydropsis meilheuratiae Chkhikvadze, 1971 (new combination).

Type material. All original material, at least a partial plastron, has never been figured and has been reported lost (Broin 1977). 
Type locality. Saint-Gérand-le-Puy, Department of Allier, France; MN 2, Aquitanian, Early Miocene (Aguilar et al. 1997).

Comments. Pomel (1846) named Emysaurus meilheuratiae in two short sentences in his summary of the turtle fauna from Saint-Gérand-le-Puy, France. The material on which this taxon was based was never figured and now seems to be lost (Broin 1977). It is clear from context, however, that Pomel (1846) at least had access to a plastron and that he purposefully placed his new taxon in the extant genus Emysaurus Duméril and Bibron, 1835, a junior synonym of Chelydra Schweigger, 1812. Some authors have since presumed that Pomel (1846) indeed described a pan-chelydrid (e.g., Chkhikvadze 1971; Broin 1977), but I find this to be purely speculative. I therefore interpret this taxon as a nomen dubium. Broin (1977) reports definite panchelydrid material from the type locality of E. meilheuratiae, but I do not consider Pomel (1846) to be an appropriate citation for this record.

\section{Hoplochelys caelata Hay, 1908a nomen dubium}

Taxonomic history. Hoplochelys caelata Hay, 1908a (new species); Protochelydra caelata Hutchison, 2008 (new combination).

Type material. USNM 5958 (holotype), left peripherals VII-IX, right peripherals VIII-X and fragmentary costals (Hay 1908a, figs. 1-3).

Type locality. Section 35, T6N, R15E, Sweet Grass County, Montana, USA; Fort Union Formation, Paleocene (Hay 1908a).

Comments. Hoplochelys caelata is based on a few shell fragments from Paleocene sediments exposed in Montana (Hay 1908a). I agree with Hutchison and Holroyd (2003) that the flat peripherals and crenulated texture of the costals are more typical of a pan-chelydrid, but I find these remains to be far too fragmentary to allow any rigorous comparison with other pan-chelydrids. I therefore disregard this taxon as a nomen dubium.

\section{Hydraspis oeningensis Fitzinger, 1836 nomen nudum}

Material. Not applicable.

Locality. Not applicable.

Comments. Fitzinger (1836) provided a new taxonomy of turtles in a Latin compendium that includes full synonymy lists and references, but he refrained from listing characters or discussing taxonomic decisions. Some fossil taxa are listed in this contribution, but no information is provided beyond the name itself. This list includes the taxon Hydraspis oeningensis, which may perhaps be an allusion to the unnamed chelydrid that Bell (1832) had reported just a few years earlier from Öhningen, Germany. Meyer (1852) and Maack (1869) attributed the name "oeningensis" to Bell $(1832,1836)$, and Lydekker (1889) and Kuhn (1964) assigned the name to Meyer (1845), but I cannot confirm these assertions. The name $H$. oeningensis is therefore fully attributable to Fitzinger (1836). The ICZN (1999) demands little of names published during the 18th and 19th centuries, but a taxon must as least be associated with a description, definition or an indication, which may include a reference to a publication that provides a description or definition. Given that Fitzinger (1836) does not satisfy any of these requirements, it is apparent that this name is a nomen nudum.

\section{Leptochelys braneti Bergounioux and Crouzel, 1965 unavailable name}

Material. MNHN SA2023 (holotype), a partial hyo/hypoplastron (Bergounioux and Crouzel 1965, fig. 5).

Locality. Sansan, Department of Gers, France (Bergounioux and Crouzel 1965; Figure 5); MN 6, Langhian, Middle Miocene (Aguilar et al. 1997).

Comments. Leptochelys braneti is emblematic of the taxonomic doublethink practiced by Bergounioux. This taxon is based on a partial hyo/hypoplastron that Bergounioux and Crouzel (1965) originally interpreted as representing a carettochelyid, but that Chkhikvadze (1971) soon after correctly recognized to be a pan-chelydrid. More strangely, however, Bergounioux and Crouzel (1965) had already noted in the type description that L. braneti is the junior synonym of Trionyx sansaniensis Bergounioux, 1935. They therefore created a taxon that they already believed to be invalid during the naming process. Following the ICZN (1999), a taxon that is not treated as valid in the type description cannot be considered available. Given that up to four names are based on material from Sansan (see Broilia robusta), of which L. braneti could at best be shown to be a junior synonym, removing this taxon from consideration has little effect on the overall taxonomy of the group.

\section{Macrocephalochelys pontica Pidoplichko and Tarashchuk, 1960 nomen invalidum (= Chelydropsis murchisoni [Bell, 1836])}

Taxonomic history. Macrocephalochelys pontica Pidoplichko and Tarashchuk, 1960 (new species); Chelydropsis (formerly Trionyx) nopcsai $=$ Chelydra strausi $=$ Macrocephalochelys pontica $=$ Testudo grandis Chkhikvadze, 1980 (junior synonym); Chelydropsis pontica Mlynarski, 1980b (new combination).

Type material. IZASU 42-1 (holotype), the slight deformed right half of a skull (Pidoplichko and Tarashchuk 1960, figs. 1-4).

Type locality. Odessa, Odessa Oblast/Province, Ukraine; Messinian, Late Miocene (Pidoplichko and Tarashchuk 1960).

Comments. Macrocephalochelys pontica is based on a relatively well-preserved and well-figured right half of a skull from Late Miocene ("Pontian") sediments exposed in Odessa, western Ukraine (Pidoplichko and Tarashchuk 1960). Tarashchuk (1971) later referred an unfigured mandible from the type locality to the same taxon, as well as a beautifully preserved and wellfigured skull, which had been collected in similarly dated 
sediments on the Crimean peninsula farther to the east along the Black Sea coast.

Chkhikvadze (1980) united all then-known Pliocene chelydrids from Europe into a single taxon. The list of synonyms includes the purported trionychid Trionyx nopcsai Szalai, 1934; the purported tortoise Testudo grandis Macarovici and Vancea, 1959 (see Testudo grandis below); and the chelydrids Chelydra strausi and Macrocephalochelys pontica. Given the priority of nopcsai over the other names, Chkhikvadze (1980) introduced the new combination Chelydropsis nopcsai for this assemblage of material, and Hutchison (2008) replicated this decision. However, given that the type material of Trionyx nopcsai includes unambiguous, though lost pan-trionychid shell fragments in addition to a partial, purported pan-chelydrid mandible, Farkas (1995) designated the jaw fragment as the lectotype of Chelydropsis nopcsai.

Whereas I agree that part of the original syntype series of Testudo grandis is pan-chelydrid in nature (see Testudo grandis below), I have come to disagree with the conclusion of Mlynarski (1966) and subsequent authors that Trionyx nopcsai is a pan-chelydrid. The lectotype of this taxon is the symphysis of a fragmentary mandible. The skull and mandibles of pan-chelydrids are short, and their mandibles therefore have an obtuse angle at the symphysis (Gaffney 1972; Mlynarski 1980b). By contrast, the skulls and mandibles of pan-trionychids are elongate, and their symphysis therefore exhibits an acute angle. The triturating surface at the symphysis is furthermore narrow in pan-chelydrids, but somewhat broadened in pan-trionychids. The lectotype of Trionyx nopcsai does not resemble a panchelydrid in both regards, and I therefore think the original identification as a pan-trionychid to be more reasonable. Given that I refer all diagnostic Pliocene pan-chelydrid material from Europe to Chelydropsis murchisoni, this conclusion has little effect on the taxonomy being presented here. However, if future authors decide to resurrect a Pliocene taxon, Chelydropsis pontica would be the correct name attribution.

Although some European chelydrids had previously been known from skulls (e.g., Meyer 1845, 1852), their morphology was only poorly known because they were typically preserved crushed and in rock slabs. The beautifully preserved skull of Macrocephalochelys pontica therefore provides much fuel regarding the phylogenetic position of this taxon. Pidoplichko and Tarashchuk (1960) presumed this taxon to be a platysternid because the skull is notably high and the jugal does not contribute to the posterior margin of the eye, characters otherwise associated with Platysternon megacephalum. This hypothesis was supported by the phylogenetic arrangement of Gaffney (1975b), which placed M. pontica as sister to P. megacephalum, deep within crown Chelydridae. Chkhikvadze (1971), by contrast, argued that $M$. pontica is a pan-chelydrid and that platysternids were not closely related with these at all. The latter conclusion is now universally accepted based on molecular (e.g., Parham et al. 2006) and morphological (e.g., Lambertz et al. 2010) data, and all similarities of $P$. megacephalum with pan-chelydrids should now be viewed as convergences.

\footnotetext{
Macrochelys floridana Hay, 1907 nomen invalidum

(junior synonym of Chelydra serpentina [Linnaeus, 1758])
}

Taxonomic history. Macrochelys floridana Hay, 1907 (new species); Macrochelys temminckii = Macrochelys floridana Auffenberg, 1957 (junior synonym); Chelydra floridana Thomas et al., 2014 (new combination and lectotype designation).

Type material. USNM 16676 (lectotype), an isolated peripheral (Hay 1907, figs. 2 and 3; Hay 1908b, figs. 284 and 285); USNM 16674, 16675, 16677 (lectotypes), three isolated peripherals (Hay 1907, figs. 1 and 4; Hay 1908b, figs. 283 and 286)

Type locality. Hillsborough County, Florida, USA; Pleistocene (Hay 1907).

Comments. Macrochelys floridana was originally based on four isolated peripherals from poorly dated Pleistocene sediments in Hillsborough County, Florida (Hay 1907), but Thomas et al. (2014) recently designated one of these four elements as the lectotype for this taxon, as they felt it to display the most diagnostic features. Auffenberg (1957) synonymized M. floridana with M. temminckii but did not provide an explicit rationale for this synonymy, although he did state that he used for comparison significant fossil and extant skeletal material held at UF. Thomas et al. (2014) more recently cited similar specimens at UF as evidence that $M$. floridana actually represents a valid taxon of giant common snapping turtle and suggested the new combination Chelydra floridana. However, it is not possible to reproduce this claim as none of the relevant material is figured or described.

I have since been able to view much of the relevant material at UF and agree with Thomas et al. (2014) that Macrochelys floridana indeed is referable to Chelydra, as the beautifully preserved skeletons closely correspond in their morphology to extant Chelydra serpentina. It is a matter of taxonomic preference, however, whether this material is viewed as a distinct species or as an enlarged Pleistocene form of the extant Florida snapping turtle Chelydra serpentina osceola. Given that I prefer naming lineage herein, I synonymize M. floridana with Chelydra serpentina but otherwise urge the description of the important material mentioned previously.

\section{Testudo grandis Macarovici and Vancea, 1959 nomen dubium}

Taxonomic history. Testudo grandis Macarovici and Vancea, 1959 (new species); Chelydropsis (formerly Trionyx) nopcsai = Chelydra strausi $=$ Macrocephalochelys pontica $=$ Testudo gran dis Chkhikvadze, 1980 (junior synonym).

Type material. GIUI uncat. (lectotype), a peripheral (Macarovici and Vancea 1959, pl. 1.12); GIUI uncat. (paralectotypes), three shell fragments (Macarovici and Vancea 1959, pl. 2.7-9).

Type locality. Măluşteni, Vaslui County, Romania (Macarovici and Vancea 1959); MN 15, Zanclean, Early Pliocene (Aguilar et al. 1997).

Comments. Testudo grandis was originally described based on at least four figured turtle shell fragments from the Pliocene of eastern Romania (Macarovici and Vancea 1959). Mlynarski (1969) soon after noted that the material consists of a mixture of pan-testudinid and pan-chelydrid remains. Chkhikvadze (1980) 
agreed with this assessment and therefore synonymized T. gran dis with other Pliocene pan-chelydrids to form his comprehensive taxon Chelydropsis nopcsai (see Macrocephalochelys pontica above). Given that I find it undesirable to have chimeric type series, I herein designate as the lectotype of " T." grandis the large peripheral fragment that Mlynarski (1969) correctly identified as a pan-chelydrid. However, given that a single peripheral is not sufficient to diagnose a turtle taxon, I here additionally consider "T." grandis to be a nomen dubium.

\section{Trionyx sansaniensis Bergounioux, 1935 nomen invalidum \\ (= Chelydropsis murchisoni [Bell, 1836])}

Taxonomic history. Trionyx sansaniensis Bergounioux, 1935 (new species); Chelydropsis sansaniensis Broin, 1977 (new combination).

Type material. MHNT SAN1163 (holotype), fragmentary right hyo/hypoplastron (Lapparent de Broin 2000, fig. 1).

Type locality. Sansan, Department of Gers, France (Bergounioux 1935); MN 6, Langhian, Middle Miocene (Aguilar et al. 1997).

Comments. The Miocene locality of Sansan in southwestern France has a long history of research. Lartet (1851) initially reported six species of fossil turtles from this locality, but given that he did not provide figures or specimen numbers most, if not all, of these should be considered nomen dubia (see Emys sansaniensis above). In his review of the fossil turtles of the Aquitaine Basin, Bergounioux (1935) recognized Lartet's taxa but nevertheless established yet another, Trionyx sansaniensis. The holotype, a partial right hyo/hypoplastron, was first presumed to be lost (Broin 1977) but could later be relocated and figured (Lapparent de Broin 2000). Broin (1977) already noted the pan-chelydrid nature of this taxon and therefore proposed the new combination Chelydropsis sansaniensis.

Under normal circumstances, the holotype of Chelydropsis sansaniensis should be considered undiagnostic, but the accumulative turtle material found at Sansan provides deep insights into the morphology of this pan-chelydrid (Broin 1977, Lapparent de Broin 2000). Broin (1977) already noted great similarities of the Chelydropsis sansaniensis with Chelydropsis murchisoni, but she nevertheless maintained the validity of this taxon, particularly based on nuances to the shape of the plastral bones. Following the rationale I developed herein (see Chelydropsis murchisoni above), I interpret these observations as interspecific variation and synonymize Chelydropsis sansaniensis with the nearly coeval type material of Chelydropsis murchisoni.

\section{Acknowledgments}

I would like to thanks Larissa Desantis, Boris Ekrt, Ursula Göhlich, Jirí Kvacek, Markus Moser, Thomas Schossleitner, Markus Wilmsen and Irene Zorn for helping me explore the whereabouts of problematic type specimens. Igor Danilov, Denis Ruez, Francois Rappaz and Halim Zinaoui were instrumental in obtaining often- obscure references. I would like to thank Vera Kalberguenova and Natalia Levkovych with transcribing and translating Cyrillic literature and Virginie Volpato for spell-checking French literature. Finally, I would like to thank Jason Bourque and Richard Hulbert for providing me access to collections at UF and insights into the taxonomy of Neogene chelydrids. Igor Danilov, Giorgos Georgalis, and an anonymous reviewer provided many critical comments that significantly helped improve the quality of the paper.

Received 9 October 2015; revised and accepted 1 February 2016.

\section{Appendix 1 \\ Institutional Abbreviations}

AMNH American Museum of Natural History, New York, New York, USA

BMNH Natural History Museum, London, United Kingdom

BSPG Bayerische Staatssammlung für Paläontologie und Geologie, Munich, Germany

FGS Geological Survey of Florida, collections now at UF or USNM

FMNH Field Museum of Natural History, Chicago, Illinois, USA

GIUI Geological Institut of the University of Iaşi, Iaşi, Romania

GPIG/GZG Geowissenschaftliches Museum der Universität Göttingen, Göttingen, Germany

IPB Steinmann-Institut für Geologie, Mineralogie und Paläontologie, Universität Bonn, Bonn, Germany

IPGAS Institute for Paleobiology of the Georgian Academy of Sciences, Tbilisi, Georgia

IZASU Institute of Zoology of the Academy of Sciences of Ukraine, Kiev, Ukraine

KU Museum, Lawrence, Kansas, USA

MHNT Muséum d'histoire naturelle de Toulouse, Toulouse, France

MNHN Muséum national d'Histoire naturelle, Paris, France

NMW Naturhistorisches Museum Wien, Vienna, Austria

SMM Science Museum of Minnesota, St. Paul, Minnesota, USA

SMNS Staatliches Museum für Naturkunde Stuttgart, Stuttgart, Germany 
SNSD-MMG Paläozoologische Sammlungen der Senckenberg Naturhistorischen Sammlungen Dresden, Museum für Mineralogie und Geologie, Dresden, Germany

UCM University of Colorado Museum of Natural History, Boulder, Colorado, USA

UCMP University of California Museum of Paleontology, Berkeley, California, USA

UF Florida Museum of Natural History, Gainesville, Florida, USA

UL1 Collection du Laboratoire de Geologie, University of Lyon 1, Lyon, France

UPV/EHU Universidad del Pais Vasco/Euskal Herriko Unibertsitatea, Bilbao, Spain

USNM United States National Museum of Natural History, Smithsonian Institution, Washington DC, USA

\section{Appendix 2 \\ Named Fossil Pan-Chelydrid Genera}

Chelydrasia Chkhikvadze, 1999 (type species: Chelydropsis minax Chkhikvadze, 1971)

Chelydrops Matthew, 1924 (type species: Chelydrops stricta Matthew, 1924)

Chelydropsis Peters, 1868 (type species: Chelydropsis carinata Peters, 1868)

Denverus Hutchison and Holroyd, 2003 (type species: Denverus middletoni Hutchison and Holroyd, 2003)

Protochelydra Erickson, 1973 (type species: Protochelydra zangerli Erickson, 1973)

\section{Appendix 3 \\ Biogeographic Summary of Fossil Pan-Chelydridae}

Numbers in brackets reference Figures 5-7. Holocene records and literature lacking vouched specimens are omitted. Abbreviations: MN, Neogene European Mammal Zone; MP, Paleogene European Mammal Zone; NALMA, North American Land Mammal Age; TL, type locality.

\section{Austria}

[1] Middle Miocene, Burdigalian/Langhian, MN 5; Eibiswald, Gratkorn, Steyeregg, Wies, Styria; Chelydropsis murchisoni (Chelydropsis carinata of Peters 1855, 1868, 1869; Gross 2002; Böhme and Vasilyan 2014)

\section{Canada}

[2] Late Cretaceous, Santonian; Alberta; Pan-Chelydridae indet. (Chelydridae indet. of Brinkman 2003)
[3] Late Cretaceous, Campanian; Alberta; Pan-Chelydridae indet. (Chelydridae indet. of Brinkman 2003; Brinkman and Eberth 2006)

[4] Late Cretaceous, Maastrichtian; Alberta; Pan-Chelydridae indet. (Chelydridae indet. of Brinkman 2003; Brinkman and Eberth 2006)

[5] Middle to Late Paleocene; vicinity of Calgary, Alberta; Protochelydra zangerli (Brinkman 2013)

[6] Middle to Late Paleocene; vicinity of Edmonton, Alberta; Protochelydra zangerli (Brinkman 2013)

\section{Czech Republic}

[7] Early Miocene, Burdigalian, MN 3; Břeštany (= Preschen) and Skyrice (= Skiritz), Ústecký Region; Chelydropsis indet. (Chelydra argillarum of Laube 1900; Chelydra sp. of Schlosser and Hibsch 1902; Chelydra murchisoni of Laube 1910)

France (see Broin 1977 for greater detail)

[8] Late Oligocene, Chattian, MP 28/29; Departments of Tarn-et-Garonne 9 and Lot-et-Garonne, Aquitaine Basin; Chelydropsis indet. (Broin 1977)

[9] Late Oligocene, Chattian, MP 25/26; Departments of Bouches-du-Rhône and Alpes-de-Haute-Provence, Rhone Basin; Chelydropsis decheni (Chelydropsis sanctihenrici of Broin 1977)

[10] Late Oligocene/Early Miocene, Chattian-Burdigalian, MP 29-MN 3; Departments of Allier, Puy-deDome, Upper Loire Valley; Chelydropsis indet. (Broin 1977)

[11] Early Miocene, Burdigalian, MN 3-4; Departments of Indre-et-Loire, Loiret, Loir-et-Cher, Maine-etLoire, Paris Basin; Chelydropsis indet. (Broin 1977)

[12] Early to Middle Miocene, Aquitanian-Langhian, MN 1-6; Departments of Aude, Gers, HauteGaronne, including Sansan (MN 6), Pyrenees Basin; Chelydropsis indet. (Broin 1977), Chelydropsis murchisoni (Chelydropsis sansaniensis of Broin 1977; Lapparent de Broin 2000; including Broilia denticulata of Bergounioux and Crouzel 1965 [in part]; Broilia robusta of Bergounioux and Crouzel 1965 [in part]; Leptochelys braneti of Bergounioux and Crouzel 1965; and Trionyx sansaniensis of Bergounioux 1935)

[13] Pliocene; Department of Pyrénées-Orientales; Chelydropsis indet. (Chelydridae indet. of Aymar 1992)

\section{Germany}

[14] Late Oligocene, Chattian, MP 30; North RhineWestphalia, Lower Rhine Embayment; Chelydra decheni (TL) (Meyer 1852, 1854, 1865)

[15] Oligocene, Chattian; Oberleiterbach, Bavaria, fissure fill; Chelydropsis indet. (Karl et al. 2011)

[16] Middle to Late Miocene, Langhian-Messinian, MN 5-13; North-Rhine-Westphalia, Lower Rhine Embayment; Chelydropsis indet. (Strauch 1990), Chelydropsis murchisoni (Klein and Mörs 2003) 
[17] Middle Miocene, Burdigalian/Langhian, MN 5; Appertshofen, Bavaria, fissure fill; Chelydropsis indet. (Groessens-Van Dyck and Schleich 1985)

[18] Middle Miocene, Serravallian, MN 7/8; BadenWürttemberg, Steinheim Basin; Chelydra murchisoni (Fraas 1870; Mlynarski 1980b)

[19] Middle Miocene, Serravallian, MN 7/8; Baden Württemberg and Bavaria, Molasse Basin; Chelydropsis indet. (Karl 2013), Chelydra murchisoni (TL) (Bell 1836; Meyer 1845, 1852; Winkler 1869; Fuchs 1939; Schleich 1981; Gaffney and Schleich 1994)

[20] Late Miocene, Tortonian, MN 9; Baden-Württemberg, Höwenegg Marr Lake; Chelydropsis indet. (Schleich 1986)

\section{Kazakhstan}

[21] Early Oligocene; East Kazakhstan, Zaisan Basin; Chelydropsis indet. (Chelydropsis minax of Chkhikvadze 1971, 1973)

[22] Late Miocene; East Kazakhstan, Zaisan Basin; Chelydropsis indet. (Chelydropsis poena of Chkhikvadze 1971, 1973)

[23] Pliocene; North Kazakhstan, Ishim River; Chelydropsis indet. (Testudo sp. of Khosatzky 1944; Chelydra sp. of Khosatzky 1967, 1982; Chelydropsis kusnetzovi of Gaiduchenko and Chkhikvadze 1985)

[24] Pliocene; Pavlodar Province; Chelydropsis kusnetzovi (Gaiduchenko and Chkhikvadze 1985; Chkhikvadze 1987)

\section{Mexico}

[25] Late Cretaceous, Campanian; Coahuila; Pan-Chelydridae indet. (Protochelydra indet. of Rodriguez-de la Rosa and Cevallos-Ferriz 1998)

\section{Moldova}

[26] Middle Miocene; Buzhory, Hînceşti District; Chely dropsis indet. (Chelydropsis murchisoni of Khosatzky and Redkozubov 1989)

[27] Pliocene; Lucești (= Lucheshty), Cahul District and Etulia, Gagaúzia District; Chelydropsis indet. (Macrocephalochelys pontica of Khosatzky and Redkozubov 1986; Chelydropsis nopcsai of Khosatzky and Redkozubov 1989)

\section{Poland}

[28] Middle Miocene, Serravallian, MN 7/8; Przeworno, Lower Silesian Voivodeship; Chelydropsis murchisoni (Młynarski 1981a, 1981b)

\section{Romania}

[29] Late Miocene, Tortonian, MN 9; Brusturi (= Tataros), Bihor (= Bihar) County; Chelydropsis indet. (Chelydra sp. of Myynarski 1966)

[30] Early Pliocene, Zanclean, MN 15; Măluşteni, Vaslui County; Chelydropsis indet. (part of Testudo grandis of
Macarovici and Vancea 1959; Chelydridae indet. of Mlynarski 1969)

\section{Slovakia}

[31] Late Pliocene, Piacenzian, MN 16; Hajnáčka, Banská Bystrica Region; Chelydropsis indet. (Chelydra decheni of Mlynarski 1963; Danilov et al. 2012)

\section{Spain}

[32] Early Miocene, Burdigalian, MN 3; Bardenas Reales, Navarre; Chelydropsis decheni (Chelydropsis apellanizi of Murelaga et al. 1999; Murelaga et al. 2002)

[33] Late Pliocene, MN 15/16; Camp dels Ninots, Catalonia; Chelydropsis indet. (Chelydropsis pontica of Claude et al. 2014)

\section{Ukraine}

[34] Late Miocene/Early Pliocene; Odessa and Kuchurhan (= Kuchurgan), Odessa Oblast/Province; Chelydropsis indet. (Testudo sp. of Khosatzky 1949; Chelydra sp. of Khosatzky 1966, 1982; Chelydropsis nopcsai of Chkhikvadze 1980, 1982), Chelydropsis murchisoni (Macrocephalochelys pontica of Pidoplichko and Tarashchuk 1960; Tarashchuk 1971)

[35] Late Miocene/Early Pliocene; Crimea; Chelydropsis murchisoni (Macrocephalochelys pontica of Tarashchuk 1971)

\section{Turkey}

[36] Early to Middle Miocene; Beşkonak (= BesKonak), Ankara Province; Chelydropsis indet. (Paicheler et al. 1978)

\section{United States of America}

[37] Late Cretaceous, Campanian; Utah; Pan-Chelydridae indet. (Chelydridae indet. of Hutchison et al. 2013)

[38] Late Cretaceous, Maastrichtian; Montana; PanChelydridae indet. (Chelydridae indet. of Holroyd and Hutchison 2002; Holroyd et al. 2014)

[39] Late Cretaceous, Maastrichtian; North Dakota; Pan-Chelydridae indet. (Chelydridae indet. of Holroyd and Hutchison 2002)

[40] Late Cretaceous, Maastrichtian; Wyoming; PanChelydridae indet. (Chelydridae indet. of Holroyd and Hutchison 2002)

[41] Early Paleocene, Puercan NALMA, Danian; Montana; Pan-Chelydridae indet. (Chelydridae indet. of Hutchison and Archibald 1986; Holroyd and Hutchison 2002; Holroyd et al. 2014)

[42] Early Paleocene, Puercan NALMA, Danian; Colorado; Denverus middletoni (TL) (Hutchison and Holroyd 2003)

[43] Middle Paleocene, Torrejonian-Tiffanian NALMAs; Montana; Pan-Chelydridae indet. (Hoplochelys caelata of Hay 1908a) 
[44] Late Paleocene, Clarkforkian NALMA, Thanetian; Alaska; Protochelydra zangerli (Hutchison and Pasch 2004)

[45] Late Paleocene, Tiffanian NALMA, SelandianThanetian; North Dakota; Protochelydra zangerli (TL) (Erickson 1973, 1982, 1984, 2010)

[46] Late Paleocene, Clarkforkian NALMA, Thanetian; Wyoming; Pan-Chelydridae indet. (Protochelydra zangerli of Bartels 1983)

[47] Early Eocene, Wasatchian NALMA, Ypresian; Wyoming; Pan-Chelydridae indet. (Chelydridae indet. of Holroyd et al. 2001)

[48] Middle Eocene, Duchesnean NALMA, Bartonian; Oregon; Pan-Chelydridae indet. (Chelydridae indet. of Hanson 1996)

[49] Early Miocene, early Hemingfordian NALMA, Burdigalian; Nebraska; Macrochelys schmidti (TL) (Zangerl 1945; Whetstone 1978a)

[50] Middle Miocene, early Barstovian NALMA, Langhian; Nebraska; Macrochelys stricta (TL) (Matthew 1924), Chelydridae indet. (Chelydra sp. of Holman and Sullivan 1981; Macrochelys indet. of Holman and Corner 1985)

[51] Middle Miocene, early Barstovian NALMA, Langhian; Florida; Macrochelys indet. (Thomas et al. 2014)

[52] Late Miocene, Clarendonian NALMA, Serravallian/Tortonian; South Dakota; Macrochelys indet. (Macrochelys temminckii of Zangerl 1945)

[53] Late Miocene, late Clarendonian NALMA, Tortonian; Florida; Chelydridae indet. (Bourque 2013)

[54] Late Miocene, early Hemphillian NALMA, Tortonian; Florida; Macrochelys auffenbergi (TL) (Dobie 1968)

[55] Late Miocene/Early Pliocene, late Hemphillian NALMA, Messinian/Zanclean; Tennessee; Chelydridae indet. (Chelydra serpentina of Bentley et al. 2011)

[56] Late Miocene/Early Pliocene, late Hemphillian NALMA, Messinian/Zanclean; Florida; Chelydridae indet., Macrochelys indet. (Thomas et al. 2014)

[57] Pliocene, Blancan NALMA; northwestern Kansas; Chelydra indet. (Galbreath 1948; Cheloniidae indet. of Hibbard 1934, 1939)

[58] Pliocene, Blancan NALMA; southwestern Kansas; Macroclemys sp., Chelydra indet. (Macroclemys temminckii and Chelydra serpentina of Hibbard 1963)

[59] Pleistocene; Idaho; Chelydra indet. (Pinsof 1998)

[60] Pleistocene; Nevada; Chelydra indet. (Van Devender and Tessmann 1975)

[61] Pleistocene; northwestern Nebraska; Chelydra indet. (Preston 1979)

[62] Pleistocene; south central Nebraska; Chelydra indet. (Preston 1979)

[63] Pleistocene; central Kansas; Chelydra indet. (Holman 1972; Preston 1979)
[64] Pleistocene; southwestern Kansas; Chelydra indet. (Galbreath 1948; Hibbard and Taylor 1960; Schultz 1965; Preston 1971, 1979)

[65] Pleistocene; Oklahoma; Chelydra indet. (Preston 1979)

[66] Pleistocene; northern Texas; Chelydra indet. (Holman 1964)

[67] Pleistocene; central Texas; Macrochelys indet. (Macrochelys temminckii of Hay 1911)

[68] Pleistocene; Missouri; Chelydra indet. (Parmalee and Oesch 1972)

[69] Pleistocene; Illinois; Chelydra indet. (Holman 1966)

[70] Pleistocene; Michigan; Chelydra indet. (Wilson 1967)

[71] Pleistocene; Ohio; Chelydra indet. (Holman 1986)

[72] Pleistocene; Maryland; Chelydra indet. (Cope 1871; Hay 1908b)

[73] Pleistocene; South Carolina; Chelydra indet. (Dobie and Jackson 1979)

[74] Pleistocene; northern Florida; Macroclemys sp., Chelydra serpentina (Chelydra floridana of Thomas et al. 2014)

[75] Pleistocene; central Florida; Macroclemys sp., Chelydra serpentina (Macrochelys floridana of Hay 1907; Chelydra laticarinata and Chelydra sculpta of Hay 1916; Macrochelys temminckii of Auffenberg 1957; Chelydra serpentina of Meylan 1995; Chelydra floridana of Thomas et al. 2014)

\section{Appendix 4 Hierarchical Taxonomy of Fossil Pan-Chelydridae}

Pan-Chelydridae Joyce et al., 2004

Chelydropsis Peters, 1868

Chelydropsis decheni (Meyer, 1852)

Chelydropsis kusnetzovi Chkhikvadze in Gaiduchenko and Chkhikvadze, 1985

Chelydropsis murchisoni (Bell, 1836)

Denverus middletoni Hutchison and Holroyd, 2003

Protochelydra zangerli Erickson, 1973

Chelydridae Swainson, 1839

Macrochelys auffenbergi Dobie, 1968

Macrochelys schmidti Zangerl, 1945

Macrochelys stricta (Matthew, 1924)

\section{Literature Cited}

Aguilar, J.-P., S. Legendre And J. Michaux, Eds. 1997. Actes du Congrès BiochroM'97, Montpellier, 14-17 avril: biochronologie mammalienne du cénozoïque en Europe et domaines reliés. Mémoires et travaux de l'Institut de Montpellier, no. 21. Montpellier, France: Ecole pratique des hautes études,. Institut de Montpellier. 817 pp. 
ANQUETIN, J. 2012. Reassessment of the phylogenetic interrelationships of basal turtles (Testudinata). Journal of Systematic Paleontology 10(1):3-45.

AuffenberG, W. 1957. The status of the turtle Macroclemys floridana Hay. Herpetologica 13(2):123-126.

AYMAR, J. 1992. Note sur la découverte d'une tortue nouvelle "Chelydropsis sp." dans le Pliocéne roussillonnais (Rus cinien). Naturalia Ruscinonensia, Revue de la Société d'Histoire Naturelle de Perpignan et des Pyrénées-Orientales, Série Générale, Section Paléontologie 2:27-32.

Barley, A.J., P.Q. SpIKs, R.C. Thomson AND H.B. SHAFFer. 2010. Fourteen nuclear genes provide phylogenetic resolution for difficult nodes in the turtle tree of life. Molecular Phylogenetics and Evolution 55(3):1189-1194.

BARTELS, W.S. 1983. A transitional Paleocene-Eocene reptile fauna from the Bighorn Basin, Wyoming. Herpetologica 39(4):359-374.

BAUR, G. 1893. Notes on the classification of the Cryptodira. American Naturalist 27:672-675.

BELL, T. 1832. Zoological observations on a new fossil species of Chelydra, from Oeningen. Proceedings of the Geological Society of London 1:342.

-1836. Zoological observations on a new fossil species of Chelydra, from Eningen. Transactions of the Geological Society of London, Series 2 4:379-381.

Bentley, C.C., J.R. Bourque, B.W. Schubert and J.I. Mead. 2011. Turtles of the Mio-Pliocene Gray Fossil Site, north eastern Tennessee. In: B.W. Schubert and J.I. Mead, eds. Gray Fossil Site: 10 Years of Research. Johnson City: Don Sundquist Center of Excellence in Paleontology, East Tennessee State University. pp. 11-14.

Bergounioux, F.-M. 1935. Contribution à létude paléontologique des chéloniens: Chéloniens fossiles du Bassin d’Aquitaine. Mémoires de la Société Géologique de France (nouvelle série), Mémoire, no. 25. Paris, Société géologique de France. 215 pp.

Bergounioux, F.-M. And F. Crouzel. 1965. Chéloniens de Sansan. Annales de Paléontologie 51:153-187.

BÖHME, M. AND D. VASILYAN. 2014. Ectothermic vertebrates from the late Middle Miocene of Gratkorn (Austria, Styria). Palaeobiodiversity and Palaeoenvironments 94:21-40.

BÖHME, W. AND M. LANG. 1991. The reptilian fauna of the Late Oligocene locality Rott near Bonn (Germany) with special reference to the taxonomic assignment of 'Lacerta' rottensis von Meyer, 1856. Neues Jahrbuch für Geologie und Paläontologie 1991:515-525.

Boulenger, G.A. 1889. Catalogue of Chelonians, Rhynchocephalians and Crocodiles in the British Museum (Natural History). London: Taylor and Francis. 311 pp.

Bourque, J.R. 2013. Fossil Kinosternidae from the Oligocene and Miocene of Florida, USA. In: D.B. Brinkman, P.A. Holroyd and J.D. Gardner, eds. Morphology and Evolution of Turtles. Dordrecht, The Netherlands: Springer. pp. 459-475.

BRINKMAN, D.B. 2003. A review of nonmarine turtles from the Late Cretaceous of Alberta. Canadian Journal of Earth Sciences 40(4):557-571.

-2013. Non-trionychid turtles from the Paleocene of Alberta, Canada. Canadian Journal of Earth Sciences 50(3):282-293.

BRINKMAN, D.B. AND EBERTH, D.A. 2006. Turtles of the Horseshoe Canyon and Scollard Formations-further evidence for a biotic response to Late Cretaceous climate change. Fossil Turtle Research 1:11-18.

Brinkman, D.B. AND R. Rodriquez DE LA Rosa. 2006. Nonmarine turtles from the Cerro del Pueblo Formation (Campanian), Coahuila State, Mexico. New Mexico Museum of Natural History and Science Bulletin 35:229-233.

BRINKMAN, D.B. AND X. WU. 1999. The skull of Ordosemys, an Early Cretaceous turtle from Inner Mongolia, People's Republic of China, and the interrelationships of Eucryptodira (Chelonia, Cryptodira). Paludicola 2:134-147.

BRoIN, F. DE. 1977. Contribution à létude des Chéloniens: Chéloniens continentaux du Crétacé et du Tertiaire de France. Mémoires du Muséum National d'Histoire Naturelle, Série C 38:1-366.

CARroll, R.L. 1988. Vertebrate Paleontology and Evolution. New York: Freeman. 698 pp.

CHKHIKVADZE, V.M. 1971. On the history of the tortoise family Chelydridae. Bulletin of the Academy of Sciences of the Georgian SSR 61:237-240. [in Russian with English abstract]

-1973. [Tertiary Turtles of the Zaisan Depression]. Tbilisi, Georgia: Metsniereba. 100 pp. [in Russian]

-1980. Systematic position of Neogene fresh-water turtles from Moldavia, the Ukraine, and some Central European countries. Bulletin of the Academy of Sciences of the Georgian SSR 99:721-724. [in Russian with English abstract]

-1982. [A large caiman turtle from Pliocene deposits of the northern Black Sea region]. Vestnik Zoologii 16:15-20. [in Russian]

- 1987. Sur la classification et les caractères de certaines tortues fossiles d'Asie rares et peu etudiees [sic]. Studia Palaeocheloniologica 2:55-86.

-1999 . The history of the development of the Paleogene herpetofauna of the former Soviet Union territory. [Problems of Paleobiology] 1:256-279. [in Russian with English summary]

Claude, J., B. Gomez de Soler, G. Campeny, J. Agusti and O. OMS. 2014. Presence of a chelydrid turtle in the late Pliocene Camp dels Ninots locality (Spain). Bulletin de la Société Géologique de France 185(4):253-256.

Cope, E.D. 1871. Synopsis of the extinct Batrachia, Reptilia and Aves of North America, Part II. Transactions of the American Philosophical Society 14:105-252.

Crawford, N.G., J.F. Parham, A.B. Sellas, B.C. Faircloth, T.C. Glenn, T.J. Papenfuss, J.B. Henderson, M.H. HANSEN AND W.B. Simison. 2015. A phylogenomic analysis of turtles. Molecular Phylogenetics and Evolution 83:250-257.

DALRYMPLE, G.H. 1977. Intraspecific variation in the cranial feeding mechanism of turtles of the genus Trionyx (Reptilia, Testudines, Trionychidae). Journal of Herpetology 11(3): 255-285.

DANILOV, I.G. 2005. Die fossilen Schildkröten Europas. In: U. Fritz, ed. Handbuch der Reptilien und Amphibien Europas; Part 3/IIIB: Schildkröten (Testudines) II. Wiebelsheim, Germany: AULA-Verlag. pp. 329-448.

-2008. An overview of fossil non-marine turtles of Europe. In: C. Corti, ed. Herpetologia Sardiniae. Latina, Italy: Edizioni Belvedere. pp. 184-187.

Danilov, I.G., A. ČERŇAnSKÝ, E.V. SyROMYATnikova AND P. JONIAK. 2012. Fossil turtles of Slovakia: New material and a 
review of the previous record. Amphibia-Reptilia 33(3-4):423-442.

DoBIE, J.L. 1968. A new turtle species of the genus Macroclemys (Chelydridae) from the Florida Pliocene. Tulane Studies in Zoology and Botany 15:59-63.

DobIE, J.L. AND D.R. JACKSON. 1979. First fossil record for the diamondback terrapin, Malaclemys terrapin (Emydidae), and comments on the fossil record of Chrysemys nelsoni (Emydidae). Herpetologica 35(2):139-145.

DuMÉRIL, A.M.C. AND G. BiBRON. 1835. Erpétologie générale ou histoire naturelle compléte des reptiles, Tome 2. Paris: Roret. $680 \mathrm{pp}$

EATON, J.G., R.L. CifelLI, J.H. HUTChISON, J.I. KiRKLAND AND J.M. PARRISH. 1999. Cretaceous vertebrate faunas from the Kaiparowits Plateau, south-central Utah. In: D.D. Gillette, ed. Vertebrate Paleontology in Utah. Miscellaneous Publication 99-1. Salt Lake City: Utah Geological Survey, Utah Department of Natural Resources. pp. 345-353.

ERICKSON, B.R. 1973. A new chelydrid turtle Protochelydra zangerli from the late Paleocene of North America. Scientific Publications of the Science Museum of Minnesota 2:1-16.

-1982. The Wannagan Creek Quarry and its reptilian fauna (Bullion Creek Formation, Paleocene) in Billings County, North Dakota. North Dakota Geological Survey Report of Investigation 72:1-17.

-1984. Chelonivorous habits of the Paleocene crocodile Leidysuchus formidabilis. Scientific Publications of the Science Museum of Minnesota 7:1-9.

-2010. Skull and mandible of Protochelydra zangerli (Testudines: Cryptodira). Scientific Publications of the Science Museum of Minnesota 8:5-12.

ERNST, C.H. 2008. Systematics, taxonomy, and geographic distribution of the snapping turtles, family Chelydridae. In: A.C. Steyermark, M.S. Finkler and R.J. Brooks. Biology of the Snapping Turtle (Chelydra serpentina). Baltimore, MD: John Hopkins University Press. pp. 5-13.

ERNST, C.H. AND R.W. BARBOUR. 1989. Turtles of the World. Washington, DC: Smithsonian Institution Press. 290 pp.

FARKAS, B. 1995. Fossil trionychid turtle types in Hungarian collections - a preliminary review (Reptilia, Testudines). Annales Historico-Naturales Musei Nationalis Hungarici 87:57-62.

FEUER, R.C. 1971. Intergradation of the snapping turtles Chelydra serpentina serpentina (Linnaeus, 1758) and Chelydra serpentina osceola Stejneger, 1918. Herpetologica 27(4): 379-384.

FITZINGER, L. 1836. Entwurf einer systematischen Anordnung der Schildkröten nach den Grundsätzen der natürlichen Methode. Annalen des Wiener Museums der Naturgeschichte 1:104-128.

FolT, B. AND C. GUYER. 2015. Evaluating recent taxonomic changes for alligator snapping turtles (Testudines: Chelydridae). Zootaxa 3947:447-450.

FrAAS, O. 1870. Die Fauna von Steinheim. Mit Rücksicht auf die miocänen Säugethier- und Vogelreste des Steinheimer Beckens. Jahreshefte des Vereins für vaterländische Naturkunde in Württemberg 1870:145-306.

Fuchs, E. 1939. Die Schildkrötenreste aus dem oberpfälzer Braunkohlentertiär. Paleontographica 89A:57-104.

GAFFNEY, E.S. 1972. An illustrated glossary of turtle skull nomenclature. American Museum Novitates 2486:1-33. -1975a. A phylogeny and classification of the higher categories of turtles. Bulletin of the American Museum of Natural History 155:387-436.

-1975b. Phylogeny of the chelydrid turtles: Study of shared derived characters in the skull. Fieldiana Geology 33:157-178.

-1979. Comparative cranial morphology of Recent and fossil turtles. Bulletin of the American Museum of Natural History 164:65-376.

-1985. The cervical and caudal vertebrae of the cryptodiran turtle, Meiolania platyceps, from the Pleistocene of Lord Howe Island, Australia. American Museum Novitates 2805:1-29.

GaffNey, E.S., P.A. MeYlan And A.R. WYss. 1991. A computer assisted analysis of the relationships of the higher categories of turtles. Cladistics 7(4):313-335.

GAFFNEY, E.S. AND H.H. SCHLEICH. 1994. New reptile material from the German Tertiary. 16. On Chelydropsis murchisoni (Bell, 1832) from the Middle Miocene locality of Unterwohlbach/South Germany. Courier Forschungsinstitut Senckenberg 173:197-213.

Gaffney, E.S., H. Tong AND P.A. Meylan. 2006. Evolution of the side-necked turtles: The families Bothremydidae, Euraxemydidae, and Araripemydidae. Bulletin of the American Museum of Natural History 300:1-698.

GAIDUCHENKO, L.L. AND V.M. CHKHIKVADZE. 1985. [First discovery of caiman turtle remains in Neogene deposits of Pavlodar Priirtyshye]. Geologiya i Geofizika 1:116-118. [in Russian]

GALBREATH, E.C. 1948. Pliocene and Pleistocene records of fossil turtles from western Kansas and Oklahoma. University of Kansas Publications, Museum of Natural History 1:281-284.

GEMEL, R. AND K. RAusChER. 2000. Fossile Schildkröten aus Österreich (Reptilia, Testudines). Stapfia 69:63-86.

GRAY, J.E. 1831. A specimen of a tortoise regarded as the type of a new genus in the family Emydidae. Proceedings of the Zoological Society of London 1:106-107.

-1847. Description of a new genus of Emydae. Proceedings of the Zoological Society of London 15:55-56.

-1856 . On some new species of freshwater tortoises from North America, Ceylon and Australia, in the collection of the British Museum. Proceedings of the Zoological Society of London 23:197-202.

-1869 . Notes on the families and genera of tortoises (Testudinata), and on the characters afforded by the study of their skulls. Proceedings of the Zoological Society of London 37:165-225.

Groessens-VAn DycK, M.-C. 1984. Les tortues du Paléocène continental de Hainin et Vinalmont (Belgique). Studia Palaeocheloniologica 1:133-139.

Groessens-VAn DycK, M.-C. AND H.H. SChleICH. 1985. New reptile material from the German Tertiary. 5. Fossil turtle remains (Chelydropsis, Trionyx) from the Miocene fissure filling of Appertshofen/N-Ingolstadt. Bulletin de la Société Belge de Géologie 94:101-112.

-1988. Nouveaux matériels de Reptiles du Tertiaire d'Allemagne. 10. Nouveau matériel du genre Ptychogaster du Basin de Mayence. Studia Geologica Salmanticensia, Volumen Especial 3:85-112.

Gross, M. 2002. Aus der paläontologischen Sammlung des Landesmuseums Joanneum - Die fossilen Schildkröten (Testudines). Joannea Geologie Paläontologie 4:5-68. 
Hanson, C.B. 1996. Stratigraphy and vertebrate faunas of the Bridgerian-Duchesnean Clarno Formation, north-central Oregon. In: D.R. Prothero and R.J. Emry, eds. The Terrestrial Eocene-Oligocene Transition in North America. Cambridge: Cambridge University Press. pp. 206-239.

Harlan, R. 1835. Medical and Physical Researches; or, Original Memoirs in Medicine, Surgery, Physiology, Geology, Zoology, and Comparative Anatomy. Philadelphia, PA: L.R. Bailey. 182 pp.

HaY, O.P. 1899. Description of two new species of tortoises from the Tertiary of the United States. Proceedings of the United States National Museum 22:21-24.

-1907. Descriptions of seven new species of turtles from the Tertiary of the United States. Bulletin of the American Natural History Museum 23:47-863.

-1908a. Description of five species of North American fossil turtles, four of which are new. Proceedings of the United States National Museum 35:161-169.

-1908b. The fossil turtles of North America. Carnegie Institution of Washington Publication 75:1-568.

-1911. A fossil specimen of the alligator snapper (Macrochelys temminckii) from Texas. Proceedings of the American Philosophical Society 50(200):452-455.

-1916. Descriptions of some Floridian fossil vertebrates, belonging mostly to the Pleistocene. Annual Report of the Florida State Geological Survey 8:39-76.

HeER, O. 1847-1853. Die Insektenfauna der Tertiärgebilde von Oeningen und von Radoboj in Croatien. 3 vols. Leipzig, Germany: Wilhelm Engelmann. $229+264+138$ pp.

-1862. Beiträge zur Insektenfauna Oeningens: Coleoptera. Geodephagen, Hydrocanthariden, Gyriniden, Brachyelytren, Clavicornen, Lamellicornen und Buprestiden. Verhandelingen Uitgegeeren Door de Hollandse Maatschappye der Wetenshappen te Harlem 16:1-90.

HibBaRD, C.W. 1934. Two new genera of Felidae from the Middle Pliocene of Kansas. Transactions of the Kansas Academy of Sciences 37:239-255.

-1939. Notes on additional fauna of Edson Quarry of the Middle Pliocene of Kansas. Transactions of the Kansas Academy of Sciences 42:457-462.

-1963. The presence of Macroclemys and Chelydra in the Rexroad fauna from the Upper Pliocene of Kansas. Copeia 1963(4):708-709.

HibBard, C.W. AND D.W. TAYLOR. 1960. Two late Pleistocene faunas from southeastern Kansas. Contributions from the Museum of Paleontology, University of Michigan 16: $1-233$.

HiRAYAma, R., D.B. BrinKMAN AND I.G. DANILOv. 2000. Distribution and biogeography of non-marine Cretaceous turtles. Russian Journal of Herpetology 7(3):181-198.

HoLl, F. 1831. Handbuch der Petrefaktenkunde. Dresden, Germany: Hilscher'sche Buchhandlung.

Holman, J.A. 1964. Pleistocene amphibians and reptiles from Texas. Herpetologica 20(2):73-83.

-1966. Some Pleistocene turtles from Illinois. Transactions of the Illinois State Academy of Science 59:214-216.

-1972. Herpetofauna of the Kanapolis local fauna (Pleistocene: Yarmouth) of Kansas. Michigan Academician 5: $87-98$

-1986. Turtles from the Late Wisconsinan of west-central Ohio. American Midland Naturalist 116:213-214.
Holman, J.A. And R.G. Corner. 1985. A Miocene Terrapene (Testudines: Emydidae) and other Barstovian turtles from south-central Nebraska. Herpetologica 41(1):88-93.

HOLMAN, J.A. AND R.M. SULLIVAN. 1981. A small herpetofauna from the type section of the Valentine Formation (Miocene: Barstovian), Cherry County, Nebraska. Journal of Paleontology 55(1):138-144.

Holroyd, P.A. AND J.H. Hutchison. 2002. Patterns of geographic variation in latest Cretaceous vertebrates: Evidence from the turtle component. Geological Society of America Special Papers 361:177-190.

Holroyd, P.A., J.H. Hutchison AND S.G. STRAit. 2001. Turtle diversity and abundance through the lower Eocene Willwood Formation of the southern Bighorn Basin. University of Michigan Papers on Paleontology 33:97-108.

Holroyd, P.A., G.P. Wilson AND J.H. Hutchison. 2014. Temporal changes within the latest Cretaceous and early Paleogene turtle faunas of northeastern Montana. Geological Society of America Special Papers 503:299-312.

HuTCHISON, J.H. 1992. Western North American reptile and amphibian record across the Eocene/Oligocene boundary and its climatic implications. In: D.R. Prothero and W.A. Berggren, eds. Eocene-Oligocene Climatic and Biotic Evolution. Princeton, NJ: Princeton University Press. pp. 451-463.

-1998. Turtles across the Paleocene/Eocene epoch boundary in west-central North America. In: M.-P. Aubry, S.G. Lucas and W.A. Berggren, eds. Late Paleocene-Early Eocene Climatic and Biotic Events in the Marine and Terrestrial Records. New York: Columbia University Press. pp. 401-408.

-2000. Diversity of Cretaceous turtle faunas of eastern Asia and their contribution to the turtle faunas of North America. Paleontological Society of Korea Special Publication $4: 27-38$.

-2008. History of fossil Chelydridae. In: A.C. Steyermark, M.S. Finkler and R.J. Brooks. Biology of the Snapping Turtle (Chelydra serpentina). Baltimore, MD: John Hopkins University Press. pp. 14-30.

-2013. New turtles from the Paleogene of North America. In: D.B. Brinkman, P.A. Holroyd and J.D. Gardner, eds. Morphology and Evolution of Turtles. Dordrecht, The Netherlands: Springer. pp. 477-497.

HutCHISON, J.H. AND J.D. ARCHIBALD. 1986. Diversity of turtles across the Cretaceous/Tertiary boundary in northeastern Montana. Palaeogeography, Palaeoclimatology, Palaeoecology 55(1):1-22.

HutChison, J.H. And D.M. BRamble. 1981. Homology of the plastral scales of the Kinosternidae and related turtles. Herpetologica 37(2):73-85.

Hutchison, J.H. AND P.A. Holroyd. 2003. Late Cretaceous and early Paleocene turtles of the Denver Basin. Rocky Mountain Geology 38(1):121-142.

Hutchison, J.H., M.J. Knell and D.B. BRINKMAN. 2013. Turtles from the Kaiparowits Formation, Utah. In: A.L. Titus and M.A. Loewen, eds. At the Top of the Grand Staircase: The Late Cretaceous of Southern Utah. Bloomington: Indiana University Press. pp. 295-318.

HutChison, J.H. AND A.D. PASCH. 2004. First record of a turtle (Protochelydra, Chelydridae, Testudines) from the Cenozoic of Alaska (Chickaloon Formation, Paleocene-Eocene). PaleoBios 24(1):1-5. 
[ICZN] INTERNATIONAL COMMISSION ON ZOOLOGICAL NOMENClATURE. 1986. Opinion 1377. Chelydra osceola Stejneger, 1918 given nomenclatural precedence over Chelydra laticarinata Hay 1916 and Chelydra sculpta Hay, 1916 (Reptilia Testudines). Bulletin of Zoological Nomenclature 43(1):33-34.

-1999. International Code of Zoological Nomenclature. 4th ed. London: International Trust for Zoological Nomenclature. 306 pp.

JoYCE, W.G. 2007. Phylogenetic relationships of Mesozoic turtles. Bulletin of the Peabody Museum of Natural History 48(1):3-102.

JoYCE, W.G. AND C.J. BeLl. 2004. A review of the comparative morphology of extant testudinoid turtles (Reptilia: Testudines). Asiatic Herpetological Research 10:53-109.

Joyce, W.G. AND J.R. Bourque. 2016. A review of the fossil record of turtles of the clade Pan-Kinosternoidea. Bulletin of the Peabody Museum of Natural History 57(1):57-95.

JoYCE, W.G. AND T.R. LYSON. 2015. A review of the fossil record of turtles of the clade Baenidae. Bulletin of the Peabody Museum of Natural History 56(2):147-193.

JoyCE, W.G., J.F. PARHAM AND J.A. GAUTHIER. 2004. Developing a protocol for the conversion of rank-based taxon names to phylogenetically defined clade names, as exemplified by turtles. Journal of Paleontology 78(5):989-1013.

KARG, J.M. 1805. Ueber den Steinbruch zu Oeningen bey Stein am Rheine und dessen Petrefacte. Denkschriften der Vaterländischen Gesellschaft der Aerzte und Naturforscher Schwabens 1:1-74.

KARL, H.-V. 1990. Erstnachweis einer fossilen Schnappschildkröte (Testudines, Chelydridae) im marinen Mitteloligozän der DDR. Mauritiana 12:477-481.

-2013. Die fossilen Schildkröten aus der Molasse von Oberschwaben mit taxonomischen Notizen zu "Promalacoclemmys Reinach, 1900” und Testudo antiqua Bronn, 1831 (Testudines: Cryptodira). Mainzer Naturwissenschaftliches Archiv 50:121-146.

Karl, H.-V., E. GRÖnING and C. BrauckMann. 2011. New Oligocene turtle remains of the Oberleichtersbach Doline filling (Lower Franconia, Germany) and revision of the genus Palaeomauremys (Testudines: Geoemydidae). Studia Geologica Salmanticensia 47(2):175-194.

KarL, H.-V., E. Gröning, C. Brauckmann, M. Reich and A. GEHLER. 2012. Revision of Chelydra strausi Schmidt, 1966 (Testudines: Chelydridae: Chelydropsinae) from the Late Pliocene of Willershausen, Germany. Studia Palaeocheloniologica 4:217-230.

KHOSATZKY, L.I. 1944. [Discovery of remains of a giant tortoise in Pliocene deposits of northern Kazakhstan]. Priroda 1:80-82. [in Russian]

-1949. [About gigantic turtles from the Pliocene of Ukraine]. Doklady Akademii Nauk SSSR 64:387-389. [in Russian]

-1966. [New data on the reptile fauna from the Pliocene of Moldova]. In: Materialy nauchnoy konferentsii po itogam issledovatel'skoy raboty za 1965 god. Kishinev, Moldova: Kartya Moldovenyaske. pp. 129-131. [in Russian]

-1967. [Cenozoic terrestrial reptiles of the Asiatic part of the USSR]. In: Stratigrafiya i Paleontologiya Mesozoyskikh i Paleogen-Neogenovykh Kontinental'nykh Otlozheniy Aziatskoy Chasti SSSR. Leningrad: Nauka. pp. 215-218. [in Russian]
-1982. [Reptiles]. In: Stratigrafiya SSSR. Chetvertichnaya sistema. Polutom 1. Moscow: Nedra. pp. 252-262. [in Russian] KHOSATZKY L.I. AND O.I. ReDKOZUBOV. 1986. [A jaw of a snapping turtle from the Pliocene of Moldavia]. In: PliotsenAntropogenovaya Fauna Denstrovsko-Prutskogo Mezhdurechya. Kishinev, Moldova: Shtiintsa. pp. 51-62. [in Russian]

-1989. [Neogene turtles of Moldavia]. Kishinev, Moldova: Shtiintsa. 94 pp. [in Russian]

KHOSATZKY, L.I. AND V.E. TOFAn. 1970. [Past and present state of the herpetofauna of Moldavia]. Uchenye Zapiski Tiraspol'skogo Gosudarstvennogo Pedagogicheskogo Instituta 20:157-181. [in Russian]

KleIn, N. AND T. Mörs. 2003. Die Schildkröten (Reptilia: Testudines) aus dem Mittel-Miozän von Hambach (Niederrheinische Bucht, NW-Deutschland). Palaeontographica A 268:1-48.

Knauss, G.E., W.G. Joyce, T.R. Lyson and D. Pearson. 2011. A new kinosternoid from the Late Cretaceous Hell Creek Formation of North Dakota and Montana and the origin of the Dermatemys mawii lineage. Paläontologische Zeitschrift 85(2):125-142.

KRENZ, J.G., G.J.P. NAYLOR, H.B. SHAFFER AND F.J. JANZEN. 2005. Molecular phylogenetics and evolution of turtles. Molecular Phylogenetics and Evolution 37(1):178-191.

KuHN, O. 1964. Fossilium Catalogus, Volume 1: Animalia, Part 107, Testudines. 's-Gravenhage, The Netherlands: Ysel Press. 299 pp.

Lambertz, M., W. BÖHme AND S.F. Perry. 2010. The anatomy of the respiratory system in Platysternon megacephalum Gray, 1831 (Testudines: Cryptodira) and related species, and its phylogenetic implications. Comparative Biochemistry and Physiology Part A: Molecular \& Integrative Physiology 156(3):330-336.

LAPPARENT DE BRoIn, F. DE. 2000. Les chéloniens de Sansan. Mémoires du Muséum National d'Histoire Naturelle 183:219-261.

-2001. The European turtle fauna from the Triassic to the present. Dumerilia 4(3):155-217.

LARTET, E. 1851. Notice sur la colline de Sansan, suivie d'une récapitulation des diverses espèces d'animaux vertébrés fossiles, trouvés soit a Sansan, soit dans d'autres gisements du terrain Tertiaire Miocène dans le Bassin sous-Pyrénéen. Auch, France: Portes. 45 pp.

LAUBE, G.G. 1900. Neue Schildkröten und Fische aus der böhmischen Braunkohlenformation. Abhandlungen des Deutschen Naturwissenschaftlich-Medizinischen Vereins für Böhmen "Lotos" 2:37-56.

-1910. Vogel- und Reptilienreste aus der Braunkohle von Skiritz bei Brüx. Lotus 58:115-127.

LindEMAN, P.V. 2003. Sexual difference in habitat use of Texas map turtles (Emydidae: Graptemys versa) and its relationship to size dimorphism and diet. Canadian Journal of Zoology 81(7):1185-1191.

LinNaEus, C. 1758. Systema Naturae, Volume 1. 10th ed. Holmia: Laurentius Salvius. 824 pp.

LyDEKKER, R. 1889. Catalogue of the Fossil Reptilia and Amphibia in the British Museum (Natural History), Part 3: Chelonia. London: Longmans. 239 pp.

MAACK, G.A. 1869. Die bis jetzt bekannten fossilen Schildkröten und die im oberen Jura bei Kelheim (Bayern) und 
Hanover neu aufgefundenen ältesten Arten derselben. Palaeontographica 18:193-336.

MACAROVICI, N. AND S. VANCEA. 1959. Sur les restes de tortues de la faune de Malusteni de la Moldavie méridionale (R.P. Roumaine). Annales des Sciences de l'Université de Jassy, 2. Sciences Naturelles 6:377-386.

MatтHEW, W.D. 1924. Third contribution to the Snake Creek fauna. Bulletin of American Natural History 50:59-210.

MEYER, H. vON. 1845. Zur Fauna der Vorwelt. Fossile Säugethiere, Vögel und Reptilien aus den Molasse-Mergel von Oeningen. Frankfurt am Main, Germany. 52 pp.

-1852. Ueber Chelydra murchinsoni und Chelydra decheni. Palaeontographica 2:237-247.

-1854. Ueber den Jugendzustand der Chelydra decheni aus der Braunkohle des Siebengebirges. Paleontographica 4:56-60.

-1865. Zu Chelydra decheni aus der Braunkohle des Siebengebirges. Palaeontographica 15:41-47.

MeYLAN, P.A. 1995. Pleistocene amphibians and reptiles from the Leisey Shell Pit, Hillsborough County, Florida. Bulletin of the Florida Museum of Natural History 37:273-297.

MeYLAn, P.A. AND E.S. GafFney. 1989. The skeletal morphology of the Cretaceous Cryptodiran turtle, Adocus, and the relationships of the Trionychoidea. American Museum Novitates 2941:1-60.

MlyNARSKI, M. 1963. Die plio-pleistozänen Wirbeltierfaunen von Hajnáčka und Ivanovce (Slovakei), CSSR. IV. Schildkröten - Testudines. Neues Jahrbuch für Geologie und Paläontologie, Abhandlungen 118:231-244.

-1966. Die fossilen Schildkröten in den ungarischen Sammlungen. Acta Zoologica Cracoviensia 11:223-288.

-1969 . Remarks on the fossil chelonians from Malusteni in southern Moldavia, Romania. Acta Zoologica Cracoviensia 14:151-162.

-1976. Testudines. In: O. Kuhn, ed. Encyclopedia of Paleoherpetology, Part 7. Stuttgart, Germany: Gustav Fischer Verlag. $130 \mathrm{pp}$.

-1980a. Die pleistocänen Schildkröten Mittel-und Osteuropas (Bestimmungsschlüssel). Folia Quaternaria 52:1-45.

-1980b. Die tertiären Wirbeltiere des Steinheimer Beckens. Teil II. Die Schildkröten des Steinheimer Beckens. B. Chelydridae mit einem Nachtrag zu den Testudinoidea. Palaeontographica, Supplement 8:1-35.

-1981a. Chelydropsinae, the Euroasiatic fossil snapping turtles (Chelydridae). Chelonologica 2:57-63.

-1981b. Chelydropsis murchisoni (Bell, 1832) (Testudines, Chelydridae) from the Miocene of Przeworno in Selesia (Poland). Acta Zoologica Cracoviensia 25:219-226.

MÖRS, T. 2002. Biostratigraphy and paleoecology of continental Tertiary vertebrate faunas in the Lower Rhine embayment (NW-Germany). Netherlands Journal of Geosciences 81:177-183.

MURCHISON, R.I. 1832. XV.-On a fossil fox found at CEningen near Constance; with an account of the deposit in which it was imbedded. Transactions of the Geological Society of London, Series 2, 3:277-290.

Murelaga, X., F. De Lapparent de BRoin, X.P. Suberbiola AND H. AstiBIA. 1999. Deux nouvelles espèces de chéloniens dans le Miocène inférieur du bassin de l'Ėbre (Bardenas Reales de Navarre). Comptes Rendus de l'Académie des Sciences Series IIA Earth and Planetary Science 328(6): 423-429.
Murelaga, X., X.P. Suberbiola, F. de Lapparent de Broin, J.-C. Rage, S. Duffaud, H. Astibia, and A. Badiola. 2002. Amphibians and reptiles from the Early Miocene of the Bardenas Reales of Navarre (Ebro Basin, Iberian Peninsula). Geobios 35(3):347-365.

Nessov, L.A. 1987. On some Mesozoic turtles of the Soviet Union, Mongolia and China, with comments on systematics. Studia Palaeocheloniologica 2:87-102.

Paicheler, J.-C., F. De Broin, J. Gaudant, C. Mourer-ChauVire, J.-C. Rage and C. Vergnaud-GrazZin. 1978. Le bassin lacustre Miocène de Bes-Konak (Anatolie-Turquie): géologie et introduction à la paléontologie des vertébrés. Geobios 11(1):43-65.

Parham, J.F., C.R. Feldman And J.L. Boore. 2006. The complete mitochondrial genome of the enigmatic bigheaded turtle (Platysternon): Description of unusual genomic features and the reconciliation of phylogenetic hypotheses based on mitochondrial and nuclear DNA. BMC Evolutionary Biology 6:11. doi: 10.1186/1471-2148-6-11.

ParmaleE, P.W. AND R.D. OESCH. 1972. Pleistocene and recent faunas from the Brynjulfson Caves, Missouri. Illinois State Museum, Reports of Investigations 25:1-52.

Parmley, D. 1992. Turtles from the late Hemphillian (latest Miocene) of Knox County, Nebraska. Texas Journal of Science 44:339-348.

PETERS, K.F. 1855. Schildkrötenreste aus den österreichischen Tertiär-Ablagerungen. Denkschriften der Kaiserlichen Akademie der Wissenschaften, mathematisch-naturwissenschaftliche Classe 9:1-22.

-1868. Zur Kenntnis der Wirbelthiere aus den Miocenschichten von Eibiswald in Steiermark. I. Die Schildkrötenreste. Sitzungsberichte der Kaiserlichen Akademie der Wissenschaften, mathematisch-naturwissenschaftliche Classe 57:72-74.

-1869. Zur Kenntniss der Wirbelthiere aus den Miocänschichten von Eibiswald in Steiermark. 1. Die Schildkrötenreste. Denkschriften der Kaiserlichen Akademie der Wissenschaften, mathematisch-naturwissenschaftliche Classe 29:111-124.

PidoplichKo, I.G. AND V.I. TARASHCHUK. 1960. [New genus of large-headed turtle from the Pontian beds surrounding Odessa]. Zbirnik Prac Zoologichnogo Muzeyu 29:105-110. [in Ukrainian with Russian summary]

PINSOF, J.D. 1998. The American Falls local fauna: Late Pleistocene vertebrates from southeastern Idaho. Idaho Museum of Natural History Occasional Papers 36:121-145.

POMEL, A. 1846. Mémoire pour servir à la Géologie paléontologique des terrains tertiaires du département de l'Allier. Bulletin de la Société Géologique de France 3:353-373.

Popov, S.V., F. RöGL, A.Y. Rozanov, F.F. STeininger, I.G. SHCHERBA AND M. Kovac. 2004. Lithological-paleogeographic maps of Paratethys. Courier Forschungsinstitut Senckenberg 250:1-46.

PRESTON, R.E. 1971. Pleistocene turtles from the Arkalon local fauna of southwestern Kansas. Journal of Herpetology 5(3/4):208-211.

-1979. Late Pleistocene cold-blooded vertebrate faunas from the mid-continental United States. 1. Reptilia; Testudines, Crocodilia. Papers on Paleontology 19:1-53.

Rabi, M., V.B. SuKhanov, V.N. Egerova, I. Danilov and W.G. JOYCE. 2014. Osteology, relationships, and ecology of 
Annemys (Testudines, Eucryptodira) from the Late Jurassic of Shar Teg, Mongolia, and phylogenetic definitions for Xinjiangchelyidae, Sinemydidae, and Macrobaenidae. Journal of Vertebrate Paleontology 34(2):327-352.

REINACH, A. VON 1900. Schildkrötenreste im Mainzer Tertiärbecken und in benachbarten, ungefähr gleichalterigen Ablagerungen. Abhandlungen der Senckenbergischen Naturforschenden Gesellschaft 28:1-135.

RicHMOND, N.D. 1958. The status of the Florida snapping turtle Chelydra osceola Stejneger. Copeia 1958(1):41-43.

Rodriguez-DE LA Rosa, R.A. AND S.R.S. CEVAllos-Ferriz. 1998. Vertebrates of the El Pelillal locality (Campanian, Cerro del Pueblo Formation), southeastern Coahuila, Mexico. Journal of Vertebrate Paleontology 18(4): 751-764.

Romer, A.S. 1956. Osteology of Reptiles. Chicago: University of Chicago Press. 772 pp.

Scheuchzer, J.J. 1726. Homo diluvii testis et theoskopos. Zürich. 24 pp.

SCHLEICH, H.-H. 1981. Jungtertiäre Schildkröten Süddeutschlands unter besonderer Berücksichtigung der Fundstelle Sandelzhausen. Courier Forschungsinstitut Senckenberg 48:1-372.

-1982. Jungtertiäre Schildkrötenreste aus der Sammlung des naturwissenschaftlichen Museums der Stadt Augsburg. Bericht des Naturwissenschaftlichen Vereins für Schwaben 86:42-88.

-1985. Zur Verbreitung tertiärer und quartärer Reptilien und Amphibien. Münchner Geowissenschaftliche Abhandlungen 4:67-149.

-1986. Vorläufige Mitteilung zur Bearbeitung der fossilen Schildkröten der Fundstelle Höwenegg. Carolinea 44:47-50.

-1988. Paläoherpetologische Materialien und Faunenspektren aus dem Kalktertiär des Mainzer Beckens (Oberoligozän Untermiozän). Geologisches Jahrbuch A110:289-306.

SCHLEICH, H.H. AND M.-C. GROESSENS VAN DyCK. 1988. Nouveaux matériels de reptiles du Tertiaire d'Allemagne. Studia Geologica Salmanticensia, Volumen Especial 3:7-83.

Schlosser, M. AND J.E. Hibsch. 1902. Eine untermiocäne Fauna aus dem Teplitzer Braunkohlenbecken. Sitzungsberichte der mathematisch-naturwissenschaftlichen Classe der kaiserlichen Akademie der Wissenschaften 111: 1123-1152.

SCHMIDT, H. 1966. Eine Entwicklungsreihe bei Schildkröten der Gattung Chelydra. Neues Jahrbuch für Geologie und Paläontologie, Abhandlungen 125:19-28.

ScHultz, G.E. 1965. Pleistocene vertebrates from the Butler Spring local fauna, Meade County, Kansas. Papers of the Michigan Academy of Science, Arts, and Letters 50: 235-265.

SCHWEIGGER, F. 1812. Prodromus monographiae cheloniorum. Königsberger Archiv für Naturwissenschaft und Mathematik 1:271-368, 405-468.

SHafFer, H.B., P. Meylan AND M.L. McKnight. 1997. Tests of turtle phylogeny: Molecular, morphological, and paleontological approaches. Systematic Biology 46(2):235-268.

SiEBENROCK, F. 1909. Synopsis der rezenten Schildkröten mit berücksichtigung der in historischer Zeit ausgestorbenen Arten. Zoologische Jahrbücher, Supplement 10:427-618.

SMITH, H.M., R.B. SMITH AND D. ChISZAR. 1983. Chelydra osceola Stejneger, 1918 (Reptilia, Testudines): Proposed conser- vation by use of the plenary powers. Z.N.(S.)2282. Bulletin of Zoological Nomenclature 40:225-227.

STEJNEGER, L. 1918. Description of a new lizard and a new snapping turtle from Florida. Proceedings of the Biological Society of Washington 31:89-92.

STERLI, J., D. Pol AND M. LAURIN. 2013. Incorporating phylogenetic uncertainty on phylogeny-based palaeontological dating and the timing of turtle diversification. Cladistics 29(3):233-246.

STRAUCH, F. 1990. Schildkrötenfunde aus den Inden-Schichten (oberes Miozän) des rheinischen Braunkohlenreviers. Neues Jahrbuch für Geologie und Paläontologie, Monatshefte 1990:308-320.

SukHanov, V.B. 1964. Subclass Testudinata. Osnovy Paleontologii 12:354-438. [in Russian]

-2000. Mesozoic turtles of middle and central Asia. In: M.J. Benton, M.A. Shishkin, D.M. Unwin and E.N. Kurochkin eds. The Age of Dinosaurs in Russia and Mongolia. Cambridge: Cambridge University Press. pp. 309-367.

SWAINSON, W. 1839. On the natural history and classification of fishes, amphibians, and reptiles. In: D. Lardner, ed. Cabinet Cyclopaedia, Volume 2. London: Longman. 452 pp.

Syromyatnikova, E.V., I.G. Danilov, V.V. Titov and A.S. TESAKOV. 2013. New data on Neogene turtles from the European part of Russia. In: Sistematica organizmov i ee znachenie dlya biostratigrafii i paleobiogeografii. Materialy LIX sessii Paleontologicheskogo obshchestva. St. Petersburg. pp. 117-119. [in Russian]

SZALAI, T. 1934. Die fossilen Schildkröten Ungarns. Folia Zoologica et Hydrobiologica 6:97-142.

TARASHCHUK, V.I. 1971. Turtles of Neogene and Anthropogen deposits in the Ukraine. Communication I. Family Platysternidae. Vestnik Zoologii 2:56-62. [in Russian with English summary]

Teppner, W. 1914. Fossile Schildkrötenreste von Göriach in Steiermark. Mitteilungen des naturwissenschaftlichen Vereins Steiermark 50:95-117.

-1915. Ein Chelydra-Rest von Göriach. Mitteilungen des naturwissenschaftlichen Vereins Steiermark 51:474-475.

Thomas, T.M., M.C. Granatosky, J.S. Bourque, K.L. Krysko, P.E. Moler, T. Gamble, E. Suarez, E. LeOne, K.M. ENGE AnD J. Roman. 2014. Taxonomic assessment of alligator snapping turtles (Chelydridae: Macrochelys), with the description of two new species from the southeastern United States. Zootaxa 3786(2):141-165

Tong, H., J. Claude, W. Naksri, V. Suteethorn, E. Buffetaut, S. Khansubha, K. WongKo and P. YuangdetKla. 2009. Basilochelys macrobios n. gen. and n. sp., a large cryptodiran turtle from the Phu Kradung Formation (latest Jurassic - earliest Cretaceous) of the Khorat Plateau, NE Thailand. Geological Society, London, Special Publications 315:153-173.

Turtle TaXonomy Working Group. 2014. Turtles of the world, 7th edition: Annotated checklist of taxonomy, synonymy, distribution with maps, and conservation status. Chelonian Research Monographs 5:329-479.

VAN DEVENDER, T.R. AND N.T. TESSMAN. 1975. Late Pleistocene snapping turtles (Chelydra serpentina) from southern Nevada. Copeia 1975(2):249-253.

WEIGEL, R.D. 1962. Fossil vertebrates of Vero, Florida. Florida Geological Survey Special Publications 10:1-59. 
Whetstone, K.N. 1978a. Additional record of the fossil snapping turtle Macroclemys schmidti from the Marsland Formation (Miocene) of Nebraska with notes on interspecific skull variation within the genus Macroclemys. Copeia 1978(1):159-162.

-1978b. A new genus of cryptodiran turtles (Testudinoidea Chelydridae) from the Upper Cretaceous Hell Creek Formation of Montana. University of Kansas Science Bulletin 51:539-563.

Williams, E.E. 1950. Variation and selection in the cervica central articulations of living turtles. Bulletin of the American Museum of Natural History 94:511-561.

-1952. A staurotypine skull from the Oligocene of South Dakota (Testudinata, Chelydridae). Breviora 2 $1-16$.
WiLson, R.L. 1967. The Pleistocene vertebrates of Michigan. Papers of the Michigan Academy of Science, Arts, and Letters 52:197-234.

WiNKLER, T.C. 1869. Des tortues fossiles conservées dans la Musée Teyler et dans quelques autres musées. Haarlem, The Netherlands: Héritiers Loosjes. 151 pp.

Woodburne, M.O. 2004. Late Cretaceous and Cenozoic mammals of North America. Biostratigraphy and Geochronology. New York: Columbia University Press. 391 pp.

ZANGERL, R. 1945. Fossil specimens of Macrochelys from the Tertiary of the plains. Fieldiana Geology 10:5-12.

ZUG, G.R. 1971. Buoyancy, locomotion, morphology of the pelvic girdle and hindlimb, and systematics of cryptodiran turtles. Miscellaneous Publications, Museum of Zoology, University of Michigan 142:1-98. 